Insight, part of a Special Feature on Scale and Cross-scale Dynamics

\title{
The Problem of Fit between Ecosystems and Institutions: Ten Years Later
}

\author{
$\underline{\text { Carl Folke }}^{1,2},{\underline{\text { Lowell Pritchard, } \mathrm{Jr}^{3}}}^{3}$, Fikret Berkes $^{4}, \underline{\text { Johan Colding }}^{1,2}$, and $\underline{\text { Uno Svedin }}^{5}$
}

\begin{abstract}
The problem of fit is about the interplay between the human and ecosystem dimensions in social-ecological systems that are not just linked but truly integrated. This interplay takes place across temporal and spatial scales and institutional and organizational levels in systems that are increasingly being interpreted as complex adaptive systems. In 1997, we were invited to produce one of three background papers related to a, at that time, new initiative called Institutional Dimensions of Global Environmental Change (IDEG), a research activity of the International Human Dimensions Program of Global Environmental Change (IHDP). The paper, which exists as a discussion paper of the IHDP, has generated considerable interest. Here we publish the original paper 10 years later with an extended introduction and with reflections on some of the issues raised in the original paper concerning problems of fit.
\end{abstract}

\section{INTRODUCTION}

The issue of linking ecosystems to socioeconomiccultural ones is of central importance for the analysis underlying almost any action related to sustainability. Without a proper understanding of the link in its local, regional, national, continental, and global contexts, it is impossible to move into the challenges of sustainable development in its three interdependent dimensions: ecological, economic, and socio-cultural. The issues have to be addressed in all three dimensions and not only in a more limited space of two or, even worse, only one dimension. These dimensions are truly integrated in a system with numerous interactions. It is here that the issue of "fit" emerged more than a decade ago, i.e., the way in which these dimensions interplay and depend on each other. Some may interpret this as a rather trivial issue of a technical methods kind, but the binding together and synthesizing work needed requires deep reflections on the character of these systems and the ways in which they can connect to a new systemic totality. This normally has to be done in a specific geographical space, be it on a micro level or a macro level, while recognizing the drivers of change internally and externally. This is what is meant by the problem of "fit."
In the mid-1990s, this issue was highlighted and analyzed by the authors of the current paper (Folke et al. 1998b). The results were widely disseminated in a document issued by the International Human Dimensions Program (IHDP) in 1997-1998. The aim of the current publication is to make the original paper, whose text is presented in italics, accessible to a wider audience. We have inserted a few additions to and reflections on the original text. A lot of work has been published on the problem of fit during the last decade. We do not intend to provide an update or review the issue. The volume of IDGEC (institutional dimensions of global environmental change) in progress (Young et al. 2007) raises the issue and includes a paper with a few of the original authors (Galaz et al. 2007). Members of the Resilience Alliance have addressed the topic (e.g., Gunderson and Holling 2002, Berkes et al. 2003, Norberg and Cumming 2007), as have studies on institutions and common pool resources (e.g., Costanza et al. 2001, Ostrom et al. 2002, Brown 2003). In addition, several papers have been published in Ecology and Society, including in the special features on cross-scale institutions, edited by David Cash (Cash et al. 2006), and exploring resilience, edited by Brian Walker and colleagues. We start the introduction on the definition of "fit" as it was seen a decade ago in the original document (Folke et al. 1998b). 
Young and Underdal (1997) describe the issue in the following way: "The problem of fit asserts that the effectiveness and the robustness of social institutions are functions of the fit between the institutions themselves and the biophysical and social domains in which they operate." Although this [1998] paper will address the social domain of institutions, our main focus will be on institutional linkages to the biophysical domain.

By institutions we mean the humanly devised constraints that shape human interaction and the way societies evolve through time (North 1990). Institutions are made up of formal constraints (rules, laws, constitutions), informal constraints (norms of behavior, conventions, and self-imposed codes of conduct), and their enforcement characteristics; thus they shape incentives in human exchange, whether political, social, or economic. Institutions, such as property rights (the structure of rights to resources and the rules under which those rights are exercised) are mechanisms people use to control their use of the environment and their behavior toward each other (Bromley 1991). They link society to nature, and have the potential to coordinate the human and natural systems in a complementary way for both ecological and human long-term objectives (Hanna et al. 1996). They also have the potential to inhibit adaptive responses to ecosystem changes, and to combine to create gridlock and confusion in environmental management.

Our approach seeks to endogenize the role of social institutions in large-scale biophysical systems, by looking at human systems as subsystems of the ecosphere. Human systems are dependent on the structure and functioning of ecosystems. Ecosystems generate essential natural resources and ecological services (Odum 1989, Daily 1997). The capacity of ecosystems to provide this support is increasingly threatened, not only at local scales, but also at regional and global scales (Jansson et al. 1994). This is a consequence of the rapid extension of human domination, particularly during this century (Vitousek 1994). The internationalization and globalization of human activities, the growth of the human population, and the large-scale movements of people have generated novel ecological and social dynamics at regional and even planetary scales (Turner et al. 1990). Processes have become so interwoven that many actions, although local in origin, are regional and global in their effects (Turner et al. 1990, Ekins et al. 1994, Holling 1994). Incremental changes in land use, for example, influence climate change, regional biodiversity, and the evolution of new diseases (Houghton et al. 1996, Skole and Tucker 1993, McMichael et al. 1996). Understanding and coping with such complex linkages becomes an analytical and observational challenge, with the numerous feedbacks across scales in time and space, throughout the entire system of humans and nature.

The present state of the world has been characterized as one in which human management is dominant, whereas over the course of human history humans have been "managed" by their environments, both biophysical (the natural, pacesetting cycles of seasons, plagues, etc.) and social (economic epochs, cultures, etc.; Holling and Sanderson 1996). This contrast has been extended into an explicit critique of modern resource management institutions (Ludwig et al. 1993), where it is suggested that institutions should be "managed" by environmental conditions. Clearly there is a co-evolutionary nature to the fit between institutions and their environment. It is no longer fruitful to separate humans and nature, nor is it useful to fight endless disciplinary battles between "social" and "natural" science.

However, few have analyzed the interactions between social systems and key structuring processes in ecosystems. In many volumes on resource management and environmental studies humans have been treated as external to ecosystems. By contrast, studies of institutions have mainly investigated processes within the social system, treating the ecosystem largely as a "black box." Analyses of institutions seldom explicitly deal with linkages to functional diversity, key structuring processes, and resilience (capacity to survive disturbance) in ecosystems.

The problem of fit is about these linkages, and is the focus in this paper. While a general use of the word fit has to do with suitability for a task, another use of the word "fit" in English refers to a match of sizes, e.g., if the shoe fits, then it is a good match for the foot. Social and ecological systems and processes have sizes too: they have spatial and temporal dimensions (Clark 1987). The question then arises: How does the scale (temporal, spatial, functional) of an institution relate to the ecosystem being managed, and does it affect the effectiveness and robustness of the institution? Functional scales (Lee 1993) would in most contexts be called "scope," that is, the variety of processes that are covered by a given institution. 
We start the paper (Section II) with a description of a few properties of ecosystems that have implications for human use and management. Next we discuss the lack of fit between conventional management and ecosystem properties (Section III) and the social and economic causes behind ecosystem deterioration (Section IV). Following that are some real-world examples of institutions for ecological management and some social mechanisms that seem to provide an institutional fit to ecosystem processes and functions (Section V). Thereafter we discuss adaptive management and the issue of nested institutions for environmental management (Section VI). We end the paper by proposing a few research challenges in relation to the problem of fit between ecosystems and institutions (Section VII).

\section{Reflection}

The perspective of the human system as a dominant subsystem raised in the introduction in the 1998 paper has expanded and become a high-priority systems issue in the research literature on natural resource management, climate change, and sustainability. We have learned that we now live in the era of the Anthropocene (Crutzen and Stoermer 2000) in which Earth system processes from local to global scales are strongly shaped by humanity (e. g., Steffen et al. 2004, Foley et al. 2005). As is envisaged by the discussions in the climate change domain, a further and now stronger scientific basis exists, not the least codified by the Intergovernmental Panel of Climate Change (IPCC), after the past decade for the importance of the human driver in greenhouse gas phenomena and their relationship to global change. Based on such insights, the balance of focus between mitigation and adaptation has also started to shift, through, for example, the work of the Tyndall Centre in the UK. Much more has now been said on the globalization phenomena in relation to local situations, including socioeconomic drivers of change (e.g., Lambin et al. 2003, Berkes et al. 2006), but the dominant work on economic and social globalization still lacks the connection to the biosphere and ecosystem capacity. The scaling issue has been further elaborated upon, both in general and in terms of a stronger focus on the regional level, not least in terms of "best practices worldwide." Institutional research in relation to natural resource and ecosystem management has continued its progress (e.g., Young et al. 2007). Overall, progress has been made on the fit problem, although the bulk of research on societal development, sustainable development, and human futures still treats social and ecological systems as largely separate entities. We plea for a more integrated view to confront the challenges of global change. Below we will expand on these items and others whenever they appear through writings in the "old" text.

\section{PROPERTIES OF ECOSYSTEMS THAT HAVE IMPLICATIONS FOR INSTITUTIONS}

An ecosystem consists of plants, animals, and microorganisms that live in biological communities and which interact with each other and with the physical and chemical environment, with adjacent ecosystems, and with the water cycle and the atmosphere (Odum 1989). Ecosystem properties that have implications for institutions are related to energy and material stocks and flows, the temporal and spatial variability of those resources, and the complex and dynamic ways in which the underlying processes relate to one another, with ecological disturbance playing an especially important role.

\section{Ecosystems as life-support systems}

Ecological systems play a fundamental role in supporting life on Earth at all hierarchical scales. They are essential in global material cycles like the carbon and water cycles. Ecosystems produce renewable resources (food, fiber, timber, etc.) and ecological services. For example, a fish in the sea is produced by a marine food web of plants, animals, and microorganisms. The fish is a part of the ecological system in which it is produced, and the interactions that produce and sustain the fish are inherently complex. Ecological services are also generated by ecosystems; these include maintenance of the composition of the atmosphere, amelioration of climate variability, flood control and drinking water supply, waste assimilation, nutrient recycling, soil generation, crop pollination, pest regulation, food provision, biodiversity maintenance, and also maintenance of the scenery of the landscape, recreational sites, and aesthetic and amenity values (Ehrlich and Mooney 1983, Folke 1991, de Groot 1992, Daily 1997). Natural systems at genetic, species, population, and ecosystem levels all contribute in maintaining these functions and services. 
Energy flow and biogeochemical cycling set an upper limit on the quantity and number of organisms, and on the number of trophic levels that can exist in an ecosystem. The structure and functioning of an ecosystem is sustained by synergistic feedbacks between organisms and their environment. For example, the physical environment puts constraints on the growth and development of biological subsystems that, in turn, modify their physical environment.

Viewing ecosystems as life-support systems emphasizes the nature-human interface. Understanding the role of ecosystems as mere life-support systems has implications for management in a simple sense: Societies must maintain sufficient levels of natural systems to provide their need for resources and services. If ecosystems were simple, ecologicaleconomic research would consist of finding accurate production functions for ecological resources and services and fitting those functions into economic models. Complex institutional arrangements governing ecosystem management would not be necessary for solving ecological problems although they might be necessary for solving social problems; institutions would chiefly govern the level or intensity of use. In any case, ecosystems are not so simple, and neither are the institutions that govern their use.

\section{Reflection}

In 1998, many of the highlighted concepts were early markers, e.g., "Viewing ecosystems as lifesupport systems emphasizes the nature-human interface." Now researchers have consolidated and more deeply explored many of the concepts in terms of both conceptual space and empirical studies. The process of and results from the UN-supported Millennium Ecosystem Assessment (www.millenn iumassessment.org) have gained widespread recognition with the concept of "ecosystem services" as a supporting set of ideas significantly expanded since the mid-1990s. There is growing recognition among both social scientists and policy makers that not only the services themselves, but also the capacity of ecosystems shaped by human actions and governance systems to supply these services, provide the foundation for social and economic development.

\section{Ecosystems as dynamically variable systems}

In ecological systems, time matters. Ecosystem properties fluctuate according to rhythms of the earth, moon, and sun in diurnal, menstrual, and annual cycles. Human institutions for environmental management have in large measure taken these regular cycles of change into account; they are fairly easy to observe, and their repetitive nature gives opportunity to learn and adapt over time. Ecosystems change over longer time spans as well; there are semi-regular patterns that correspond to the El Niño-Southern Oscillation effect (Philander 1989), variations in insolation (Eddy 1994), cycles in orbital precession (Davis and Sellers 1994), and cycles of glaciation.

Other biophysical cycles that govern ecosystem dynamics are either not so regular or are only regular in a statistical sense. The life-spans and life histories of economically important plants and animals set the rhythms for many institutions designed to regulate the harvest and use of biotic resources. Episodic disturbances like fire, pest outbreak, storms, and landslides affect the availability of ecosystem goods and services, and have an effect on the shape of the institutions governing access to those goods and services. Because disturbances may vary on scales of time and space that are similar to those of anthropogenic changes, they form particularly thorny problems for institutions; in particular, historical contingencies may give rise to path dependence (Krugman 1991, Foster 1992, Arthur 1994).

\section{Reflection}

The general framework of complexity theory has developed in relation to complex adaptive ecosystems (e.g., Levin 1999), and at present the strong emergence of complex systems ideas and connected dynamism sets the pace for analyses of social-ecological systems. The observation of regime shifts in many ecosystems is coming more and more to the forefront (e.g., Scheffer et al. 2001, Folke et al. 2004). Ecosystems are no longer interpreted as rather stable entities that could be approached by checking their fit through simple sets of indicators to be used in the socio-cultural and economic domains. The development of historical interpretations in ecology, not the least related to food webs as a start of analysis of overfishing (e.g., Jackson et al. 2001) has heavily expanded our 
understanding of the dynamics of the processes involved. It is here that the regime shift concept enters the picture and the role of biological diversity in ecosystem functioning and resilience becomes critical (e.g., Peterson et al. 1998, Elmqvist et al. 2003, Bellwood et al. 2004). We have also seen a gradual increase in policy formulation and, to some extent, implementation.

\section{Ecosystems as spatially heterogeneous systems}

Many ecological models notwithstanding, plants, animals and abiotic elements of ecosystems are not just so many ingredients in an evenly mixed and smoothly interacting "soup." Ecosystem elements are arrayed in space variously and discontinuously, so that the properties of one piece of the landscape may not be shared by its neighbors. Resources are typically concentrated, creating some resource-rich regions and some relatively poor. Just as different management techniques will be necessary to meet particular landscape contingencies, so different institutional arrangements depend on the pattern of resources. The spatial variability of resources is a persistent form of ecosystem risk around which institutions are elaborated (Johnson and Earle 1987).

If ecosystem pattern and resource distribution were a deterministic function of soil type, rainfall, topography, and climate, institutions could stabilize around a known landscape pattern and persist or even evolve toward ever greater efficiency. However, the spatial distribution of ecosystem properties changes over time, sometimes predictably and sometimes unpredictably (Turner 1989). Many economic practices and their governing institutions are geared to alter the pattern of the landscape, and in so doing they change underlying ecosystem processes.

\section{Reflection}

During the past decade, ideas and research lines about "patchiness" have gained much momentum (see, e.g., the DYN group at the International Institute for Applied Systems Analysis). Also the development of ideas about networks of resources, especially in landscapes characterized by quickly changing dynamic processes, has come to the forefront. Exemplifications using various adaptive management approaches (e.g., the Unesco
Programme on Man and the Biosphere) on very different objects have heavily expanded in scope and diversity. The implication of a spatial dimension in natural resource and environmental economics is also a field worth exploring.

\section{Ecosystems as complex, evolving systems}

The interactions among species in a food web and their relations to water flow and biogeochemical cycling are complex and nonlinear, and contain lags and discontinuities, thresholds, and limits. Ecosystems are complex, self-organizing systems nested across temporal and spatial scales (O'Neill et al. 1986, Levin 1992). Because these systems are evolutionary rather than mechanistic, they exhibit a limited degree of predictability (Costanza et al. 1993).

Holling (1986) has described ecosystem behavior as the dynamic sequential interaction between four basic system functions (Fig. 1): exploitation, conservation, release, and reorganization. The first two are similar to ecological succession. Exploitation is represented by those ecosystem processes that are responsible for rapid colonization of disturbed ecosystems and during which organisms capture easily accessible resources. Conservation occurs when the slow resource accumulation takes place that builds and stores increasingly complex structures. Connectedness and stability increase during the slow sequence from exploitation to conservation and a "capital" of biomass is slowly accumulated. The next function is that of release or creative destruction. It takes place when the conservation phase has built elaborate and tightly bound structures that have become "overconnected," so that a rapid change is triggered. The system has become brittle. The stored capital is then suddenly released, and the tight organization is lost. The abrupt destruction is created internally but caused by an external disturbance such as fire, disease, or grazing pressure. This process of change both destroys and releases opportunity for the fourth stage, reorganization, in which released materials are mobilized to become available for the next exploitive phase.

The stability and productivity of the system is determined by the first two system functions, i.e., by the slow sequence of exploitation and conservation. Resilience, as we use the term, is different from 
Fig. 1. The four ecosystem functions $(r, K, \Omega, \alpha)$ and the flow of events among them. The arrows show the speed of that flow in the cycle, in which the arrows close to each other indicate a slowly changing situation. The cycle reflects changes in two attributes: (1) the $y$ axis shows the amount of accumulated capital potential, e.g., nutrients, carbon, stored in the variables that are the dominant structuring variables at that moment, and (2) the $x$ axis indicates the degree of connectedness among the variables. The arrows entering and leaving a phase suggest the points at which the system is most sensitive to external influence.

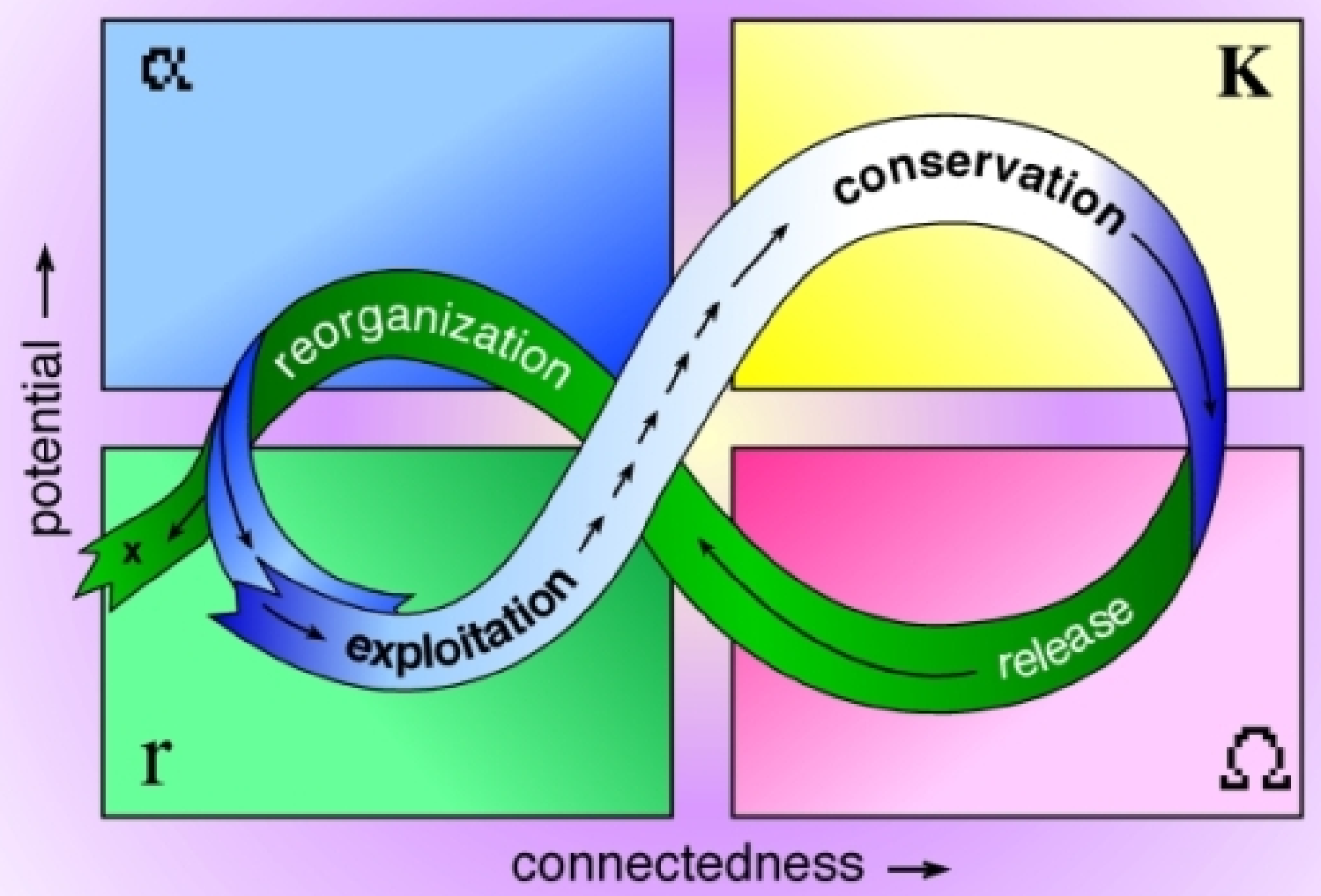

stability. Resilience is the system's capacity to survive disturbance, i.e., its capacity to undergo stress and yet recover, or even to endogenize the disturbance and transcend it (Holling 1973). Stability has to do with how resistant the system is to disturbance, crashing, or some other fundamental reorganization. Resilience is determined by the effectiveness of the last two system functions. The self-organizing ability of the system, as exhibited in release and reorganization, determines its capacity to respond to the stresses and shocks imposed by predation or pollution from external sources. Resilience conserves opportunity for renewal. 
Biological diversity seems to play an important role in ecosystem function and resilience. The degree of resilience is linked across temporal and spatial scales from reservoirs of genetic material necessary for the evolution of microbial, plant, animal, and human life to diversity over the whole landscape, the mosaic of ecosystems. Ecological research indicates that the reduction of functional diversity and loss of resilience will move the system closer to thresholds, and ultimately cause it to flip from one equilibrium state to another (Westoby et al. 1989, Holling et al. 1995). Such threshold effects occur in large-scale ecosystems, e.g., when the loss of resilience flips a tropical forest into a grassland ecosystem, or a savanna ecosystem into a bushshrub landscape. The vulnerability of key structuring processes seems to be a function of the number of organisms that can take over and run such processes when the system is perturbed (Holling et al. 1995). Loss of functional diversity and buffer capacity implies that the capacity of ecosystems to sustain the flow of essential natural resources and ecological services is being challenged (Folke et al. 1996).

Because of the organizational and temporal complexity of ecosystems, human intervention may have different effects at different times; these effects may also depend on which ecosystem components are impacted. More complex institutions may be necessary to maintain ecosystem function in the face of human use, and they may govern not just the level and intensity but the timing, spatial pattern, and specific form of resource use. In principle, there is an inherent unawareness, as well as unpredictability, concerning these evolving managed ecosystems and the societies with which they are linked. The essential point is that evolving systems require policies and actions that not only satisfy social objectives but also achieve a continually modified understanding of the evolving conditions and provide flexibility for adaptation to surprises.

\section{Reflection}

The role of biodiversity in complex adaptive ecosystems was commented upon in the previous reflection. Work on resilience has expanded considerably and is increasingly addressing the sources of social and ecological resilience and the capacity to deal with change (reviewed by Folke 2006). The challenge for policy in dealing with evolving systems has been discussed by Kinzig et al. (2003) and others.

\section{Disturbance as an important part of development}

Natural disturbances, such as events triggered by fire, wind, and herbivores, are an inherent part of the internal dynamics of ecosystems and in many cases set the timing of successional cycles (Sousa 1984). Natural disturbances are parts of ecosystem development and evolution, and seem to be crucial for ecosystem resilience and integrity (Holling et al. 1995). If they are not allowed to enter the ecosystem, it will become even more brittle, and thereby even larger perturbations will be invited with the risk of massive and widespread destruction.

One of the central features of nonlinear systems, and one that confounds management, is that small disturbances can become magnified and lead to qualitatively unexpected behaviors at more macroscopic levels; this becomes increasingly true as system complexity increases. Understanding patterns and interactions across spatial and temporal scales is critical for reducing the misfit between ecosystems and institutions.

In the case of forest fires, for example, the gradual buildup of fuel during periods without fires can provide the ingredients leading to major conflagrations. Classical management practices endeavored to suppress fires entirely, which increased both the stock of timber and thus the stock of combustible litter, creating accidents waiting to happen. Such simplistic management regimes aimed at removing local disturbances, thereby losing ecosystem robustness and resilience, and the predisposition to catastrophic large-scale fires increased. Such fires spreadfarther and burn longer and at higher temperature than otherwise, leading not just to the destruction of trees and seeds, but also to soil erosion and a deterioration in the capability of the system to recover (Levin et al. 1997).

Regular outbreaks of fire in the face of fuel accumulation on the forest floor make some kinds of forest ecosystems resilient, just as regular elections and the changes in government brought about by them may make some democratic institutions resilient (although, as seen below, regular elections may also lead to the perverse effect of management myopia). When they are accumulating fuel, or otherwise slowly changing over time, the more forests are protected from fire, the more vulnerable they become to destruction by fire. Forest managers now recognize the value of 
letting small fires burn to maintain the resilience of systems. Management regimes that actively respond to and permit some kinds of disturbance are reducing the misfit between ecosystems and institutions.

These sorts of threshold effects or flips (bifurcations) can occur in many kinds of ecosystems (Ludwig et al. 1997). The flip from one state to another is often induced by human activity, for example, by cattle ranching in savanna systems (Behnke et al. 1993, Westoby et al. 1989), overfishing and eutrophication around coral reefs (Knowlton 1992, Hughes 1994), and eutrophication of lakes (Scheffer et al. 1993). Such shifts from one equilibrium to another may be virtually permanent, as in desertification, or periodic, as, for example, in the recurrent outbreaks of forest pests or diseases such as influenza. A flip to a new state may not generate the same level of natural resources and ecological services as before, and thereby cause social and economic consequences and conflicts.

\section{Reflection}

The interplay between release and creative destruction has called for new "navigation" approaches in the management realm. This has involved far more links and phases than were involved in the mid-90s elaborations. In fact, the involvement of new elements in these webs as social (dynamic) memory and other social-ecological sources exemplifies the point. Resilience as an emerging key concept is now considered to provide not only just a buffer against shocks but also the capacity to nourish new structures that allow innovation to take place. The development of resilience features has expanded in terms of couplings of interconnected temporal and spatial scales. This has been done as an outflow of the stronger interests and capacities of analysis of highly integrated social-ecological systems (e.g., Carpenter and Brock 2006).

\section{THE LACK OF FIT BETWEEN CONVENTIONAL MANAGEMENT INSTITUTIONS AND ECOSYSTEM PROPERTIES}

Many current societies employ social norms and rules which (1) bank on future technological fixes; (2) use narrow indicators of welfare; (3) employ world views which alienate people from their dependence on life-support ecosystems; and (4) assume that it is possible to find technical substitutes for the loss of ecosystems and the services they generate (Costanza and Folke 1997). Such social norms and rules have influenced natural resource management. Natural resource management science has during the last century been geared for the efficient utilization of resources as if they were limitless, shaped by the utilitarian premises of the early industrial era. Nature was viewed merely as a storehouse of raw materials; resources were thought to be valuable only to the extent that they could be used to create wealth. Methods of resource development and management in both the biological and economic areas treated the environment as discrete boxes of "resources," the yields of which could be individually maximized (Berkes and Folke 1998).

Although many of our examples of "lack of fit" between institutions and resources are taken from industrial or commercial modern economies, we do not mean to imply that whatever is modern is maladaptive. The characteristics of institutions which do not maintain the structure and function of ecological resources are generally applicable to traditional institutions as well. We do not subscribe to belief in the "ecologically noble savage" (Redford 1990), "living in harmony with nature, enjoying its bounty and preserving the environment with sympathetic understanding" (Jamieson and Lovelace 1985). We do make the argument that in many cases proximity and direct dependence on the resource base make it easier to filter out and discard practices that are clearly unsustainable, and this close connection to nature is a property of many indigenous traditional systems.

It is true that some modern ecological problems do come from "bad ideas" (White 1967, see also the literature on ecofeminism), but modern institutions are not simply self-destructive: for one thing, they are in a state of flux, adapting themselves more or less rapidly to a fossil fuel resource base from a solar and geological resource base (Odum 1971). Disharmony arises as the social system tried to "fit" itself to two very disparate resource bases, and there is no guarantee of ultimate consonance between the rationalities of industrial development and ecological sustainability. 


\section{Reflection}

Today the remark about examples of lack of fit seems self-evident, more so than it did in the mid-1990s. However, efforts to come to grips with the fit problems are still at the research frontier (e. g., Young 2002), and are addressed also in additional fields such as archeology and anthropology (Redman 1999, van der Leeuw 2000, Diamond 2005, Schwartz and Nichols 2006).

\section{Wrong focus of resource management}

Based on this perspective, modern natural resource management has been successful at rapidly achieving a set of narrowly defined goals. It has focused on controlling the flow of specific resources into the economy such as fish, trees, water, or cattle, thereby achieving social objectives, such as employment and economic growth. The field has relied on the use of fixed rules for achieving constant yields, as in fixed carrying capacity of animals and fixed maximum sustainable yields (MSY) of fish and forest products. Success has generally been equated with increasing yields, and increasing economic returns.

This "success" has been accomplished through an active reduction of variability in the flow of the resource into the economy, to a large extent made possible by the development of new technology. The initial success changed the focus from managing natural resources to improving the efficiency of methods of resource management (including technological development). For example, bigger fishing fleets were built, and there were increased fishing efforts to maintain the yield from decreasing fish stocks. The technological "success" amplified the mental alienation of modern society from the dependence on functional ecosystems. Human ingenuity expressed in new technology was believed to be an effective conqueror of the fluctuations of nature. Management institutions, like fisheries, forestry, and agricultural and other governmental boards, became more rigid and less responsive to critical changes in the ecosystem.

It has been profoundly disturbing to analysts that, in many cases of renewable resource management, the success in managing a target resource (food, fiber) for sustained production has lead to an ultimate pathology of:
1. more brittle and vulnerable ecosystems,

2. more rigid and unresponsive management agencies, and

3. more dependent societies (Holling 1986).

Examples include the initial decades of chemical control of spruce budworm in Canadian forests, where more and more control efforts seem to result in larger and larger infestations when they do occur, and forest fire suppression in Yellowstone National Park in the United States, where almost half of the Park burned down in one major fire in 1988, following a century of fire suppression. The very success of a well managed fishery tends to trigger its own demise by attracting additional capitalization and fishing effort until all resource rents are dissipated, a well known phenomenon in fishery economics (Clark 1985). There are many examples of apparently successful management, later leading to environmental backlash or surprise; examples range from pesticide use to the damming of major African rivers (Farvar and Milton 1972).

\section{Reflection}

Issues such as fixed maximum yield approaches seem less at the cutting edge today, but, in the domain of practice and policy, these thought patterns are still very much alive. Ideas about the role of variability have greatly been expanded, for example, in relation to complex ecosystem dynamics and their management and governance (e. g., Wilson 2006). A subject of particular interest in this expanding area is the interplay between different levels of aggregation. At the level of connected management, it seems important to draw a distinction between visible and invisible market niches interplaying in the same domains. In particular, the technology drivers for this varied composition are presently emerging. This phenomenon received very little attention in the mid-1990s, when issues related to globalization were already becoming apparent, but was still not being viewed as an extremely dynamic process that enables socio-technical systems to operate at several levels simultaneously. 


\section{Short-term success leads to long-term failure}

Hence, there are more and more examples of conventional resource management that has been successful in the short term, but where experience has shown that this type of management slowly changes the functioning and resilience of the ecosystem that sustains the production of the natural resource (Gunderson et al. 1995). At the same time, conventional resource management deteriorates the capacity of the ecosystem to generate essential ecological services that other parts of society depend upon (Odum 1989, Folke 1991, de Groot 1992, Daily 1997). It is interesting that in one sense the fit between society and its institutions and the resource base becomes tighter with successful management, but that tight fit is maladaptive because it is not resilient to changes in environmental conditions. The optimal "fit" between institutions and the resources they govern may not be the tightest fit.

Conventional resource management is predisposed to reduce variability and to block out disturbances. Conventional environmental management tends to do the same with environmental problems. This may be "efficient" in a limited sense in the short term. But, as clarified in the previous section, disturbances are endogenous to the cyclic processes of ecosystem development (Holling et al. 1995). If they are not allowed to enter into the system, they will accumulate and return at a later stage on a much broader scale.

For example, intensive agriculture creates soil erosion and salinization of soils from irrigation. Instead of responding to the feedbacks from degrading agricultural ecosystems, management uses more fertilizers to compensate for loss in ecosystem productivity. Acidification provides an example of the same phenomena in environmental management. Instead of focusing on the reasons behind local air pollution, higher smokestacks were built as a remedy to air pollution. If that would have happened in only a few places in the industrial world, it might have been a long-term solution. But numerous local stacks were built, causing an accumulation of sulfur compounds in the air that has resulted in widespread regional acidification problems. A local small disturbance has turned into a large regional disturbance.

Hence, it seems like conventional resource management tends to increase the potential for larger-scale disturbances and even less predictable and less manageable feedbacks from the environment. These feedbacks, or surprises (perceived reality departs qualitatively from expectation), can have devastating effects on ecosystems and on societies that depend on the resources and services that ecosystems generate. This pattern of exploitation, the pathology of conventional resource management, seems to have been more the rule than the exception, and has been described in numerous case studies (e.g., Regier and Baskerville 1986, Acheson et al. 1997, Ludwig et al. 1993, Finlayson and McCay 1997).

\section{Reflection}

Recent articles on social and economic adaptations that have contributed to the pathology of natural resource management include studies of coastal fisheries (Huitric 2005), regional agriculture (Allison and Hobbs 2004), and possibly the global fish meal trade (Deutsch et al. 2007). The most recent articles examine the "new" global dynamics referred to above, and how the biosphere has been drawn more strongly into these processes. With this in mind, there is a need for a more vigorous focus on economic development as part of the overall systemic composition of globalization, although this subject should be addressed in the context of broader social-ecological systems context. This idea is still cutting edge, especially in its policy implications (Young et al. 2006). It is not by mere chance that the challenge identified for the UN Johannesburg conference in 2002 involved implementation mechanisms. Also, the current discussion in the EU on sustainability policy has highlighted these aspects. To some extent, this discussion has shifted the focus of analysis, even more pronounced in policy, from a more isolated green posture to the significance of the biosphere as a life-support system for social and economic development.

\section{Crisis for institutional learning?}

However, if we examine the pathology over a longer span, we find that another kind of surprise may occur. There are cases in which external and internal crises, amplified by the pathology, trigger a sudden lurch in understanding, a redesign and expansion of policy, and a return of flexibility and innovation. Under certain conditions, crisis seems 
to trigger institutional learning (Holling and Sanderson 1996). There have been enough cases to prompt a book-length exploration of examples of pathological exploitation, followed by crises and learning. Examples range from the Everglades of Florida, the forests of New Brunswick, the estuary of Chesapeake Bay, the Great Lakes, and the Baltic Sea (Gunderson et al. 1995).

In New Brunswick, for example, the intensifying deadlock in forest management, combined with slowly accumulated and communicated scientific, economic, and social understanding, led to an abrupt transformation of forest policy. Once freed from local constraints, policy could be set in an adaptive framework designed to achieve both ecological and economic benefits (Baskerville 1995). The new policy functions for a whole region by transforming and monitoring the smaller-scale stand architecture of the landscape and by releasing the productive and innovative capacities of industry.

Viewed this way, the message from pathological examples becomes entirely different. The examples indicate that pathology itself may trigger learning and innovative redesign toward sustainability. Indeed, crisis may be a necessary condition to provide the understanding for system change (Gunderson et al. 1995). The research question becomes whether one can predict certain kinds of institutional innovation from certain kinds of crises or pathologies. Crisis can be either a creative or a destructive spark, depending on the kinds of social structures that are challenged. Crisis can help agents break through dense or encrusted institutional structures to achieve useful innovations, but, if environmental crisis attach too strongly to structures of social signification, they may lead to social as well as environmental disaster $(F$. Westley, personal communication).

One way that "normal" resource crises can create social crises is if they are allowed to build up to a level where they challenge the survival of the community, a region, or society as a whole. As we learned from the collapse of the Newfoundland cod fisheries (Finlayson and McCay 1998), the price of learning from such crises may be extremely high, and social and economic consequences severe. Because ecosystems are nonlinear complex systems, the sum total of our actions may cause them to lurch to quite different, and potentially unwelcome, development branches. Thus, small changes in global mean temperature caused by numerous anthropogenic sources could lead to a shift in the Gulf Stream; extinction of certain keystone species caused by widespread land use changes may magnify into losses of ecosystem function (Levin 1997). As resilience of the ecosystem gradually declines, flexibility is reduced and ultimately lost, and the social system becomes more vulnerable to surprise and crisis (Holling et al. 1998).

\section{Reflection}

In the mid-1980s, when the concept of sustainability first emerged (see, e.g, Clark and Munn 1986, and more recently Clark et al. 2001), the issue of "social learning" was already on the table. However, researchers were still not particularly interested in ecosystem feedbacks. That has changed, and examples of the emergence of self-organized multilevel governance systems for ecosystem management in response to perceived crises are now appearing (e.g., Olsson et al. 2004a,b). Also new is work on facilitating learning for environmental management (e.g., Pahl-Wostl and Hare 2004), and studies connecting scale issues with epistemology. The earlier work suggesting the potentials of scalespecific knowledge, such as local and traditional knowledge (Berkes and Folke 1998), has been extended into discussions of the broader policy implications of bridging scales and knowledge systems (e.g., Reid et al. 2006). In general terms, it is in the last decade that the merger of the concept of the knowledge society with environmental considerations has started to gain momentum. In a political sense, the launch in the EU of the concept of the knowledge society in connection with the Lisbon agenda is a fairly recent example of this. At the political level, the connection to the environmental agenda still needs both analytical and political support. Here also the global connotations are more and more important, as, for example, could be seen in the case of global fisheries management or mismanagement. Extreme and not yet very visible cases connecting, for example, Thai aquaculture feed input from as far away as North Sea fisheries point both to the global nature and the surprising characteristics of "reversed" resource streams in the patterns of the global economy (Deutsch et al. 2007). The interplay between local and global markets is just another facet of the same coin. Examples from research projects undertaken in the last decade provide a new and stronger base for fresh insights into these fields. 


\section{ECONOMIC AND SOCIAL BARRIERS TO THE FIT BETWEEN ECOSYSTEM AND INSTITUTIONS}

Some of us have argued elsewhere that a fundamental reason for the lack of fit between institutions and ecological processes is the mental separation from nature that has arisen in modern societies. The modern world creates and tightens intersystems linkages, hierarchies, and interdependencies between local resource users and the wider society through the market, political control, and social networks. Interestingly, the result of the tightening is to distance resource users from the resource base, to disconnect production from consumption, and to disconnect the production of knowledge from its application (Jodha 1995). The separation of humans and nature has alienated society from its dependence on functional ecosystems and the support that they provide for social and economic development (Berkes and Folke 1994).

Many decisions taken in society entail ecological externalities, which accumulate and change critical properties and the capacity of ecosystem to provide support. The environmental literature has typically overemphasized simple cases of deterioration, e.g., clearing and burning of tropical forests and mangrove ecosystems, waste problems associated with urbanization, and emissions of greenhouse gases and ozone-depleting chemicals. These are the proximate causes of environmental change. Increasing attention is being paid, however, to the indirect or underlying social and economic driving forces behind the proximate causes.

\section{Underlying driving forces}

These driving forces can include tenure regimes, technological change, international financial assistance and pressure for structural adjustment, government economic and social policy, demographic change, international environmental institutions, and world commodity markets, as well as even more distant determinants of environmental change such as power relations in society, world-view, lifestyle, religion, ethics, and values. Some of these driving forces are the subject of research trying to correlate environmental change with external drivers. What is unclear in a general sense are the mechanisms by which changes in driving forces work through to impacts on the proximate causes of environmental change. There are time lags, spatial-diffusion processes, and convoluted transformations of broad-scale socioeconomic and biophysical signals. One task is to identify these time lags and diffusion processes, in itself a gargantuan task-but the further task is to specify the many variations that can invert, buffer, amplify, or otherwise transform driving forces into landscape signatures. Much of the following discussion borrows from Geoghegan et al. (1998).

For example, many researchers have found strong links between the external sector (international commodity prices and exchange rate dynamics, or ENSO oscillation) and changes in land use or cover, such as forest biomass or cropping schedules. However, these results are difficult if not impossible to generalize across regions and between nations, and simple correlations tend to fall apart. Similarly, some research postulates a straightforward link between population levels or rates of change and deforested area or deforestation rates, but such relationships typically provide no more than $50 \%$ of the explained variance in forest cover across diverse regions (Mather et al. 1998) and commonly disappear in place-specific analysis (Kasperson et al. 1996). When these supposed macro-mechanisms are not understood and set in context, even statistically significant correlations may be spurious.

\section{Reflection}

The analysis of more than a decade of major phenomena related to barriers and promoters has gradually provided stronger and stronger evidence about issues that until now have been correctly but only vaguely understood. The last decade also provided a gradual assemblage of cases that may make it possible to fundamentally revise our understanding of the factors involved. A good case is the re-interpretation of the dynamic mechanisms of land use (e.g., the LUCC project on land-use and land-cover change, Lambin et al. 2004, and other investigations) in which the population and poverty drivers that contributed so strongly to earlier explanations now have to be understood in their economic and political contexts, and in terms of how they operate in a globalized society. The classic demographic problematique has undergone major shifts because of the addition of other influential but entirely different factors, such as education levels, to our understanding of the dynamics (see, e.g., results from the International Institute of Applied 
Systems Analysis demography group under Wolfgang Lutz). Here we face strong new interpretation shifts in these domains that were highlighted in the 1990s as issues of fit. In part, these phenomena result from the inclusion, in a broader systems analysis, of factors that were once treated separately, e.g., issues about related to niche markets in connection to phenomena of ecological change. The analysis of underlying driving forces has been more refined during the last decade by increased attention to phenomena that interact on multiple scales (see, e.g., the U.S. Academy of Science reports, results from the Tyndall Centre in the UK, Berkes et al. 2006, Kinzig et al. 2006).

\section{Scale and driving forces}

The explicit recognition that driving forces vary across scales of space and time is often missing in analyses of environmental change, and the omission is even more glaring in much institutional analysis. Driving forces vary with their causal distance from decision makers, and are often typologized as proximate, intermediate, and distant (Turner et al. 1993). They can also be categorized according to the space and time scales they occupy, so that analysis of institutional forms at a particular scale will draw attention to particular driving forces (see Fig. 2). Increasingly, the discovery that "scale matters" has evolved into a more sophisticated understanding of the importance of scale.

Recognizing the importance of scale may resolve some puzzles in comparative research. The conventional thinking on scales emphasizes finding the right scale of analysis to solve particular problems, rather than using arbitrarily imposed scales. This is a useful but limited innovation: Our argument is that ecosystem properties that cause the most trouble for management are those that are linked across scales. This argues for a multiscale approach to institutional analysis, at the very least. Working at multiple scales, however, has frequently been reduced to farming out research at different scales to different researchers, then compiling the results in an edited volume and calling it multiscale analysis. Innovative working at multiple scales involves crossing and linking scales, i.e., not just multiple scale analysis, but cross-scale analysis (see Table 1).

As has been said in reference to nested scales (indeed, it has been a specific complaint against
Fig. 2), "the world is not a set of Chinese boxes." Static approaches to hierarchy theory are satisfied with a snapshot of processes describing the scales at which they operate. In the real world, it is found that these scales change over time (Gunderson et al. 1997). Many of the problems and processes to be addressed have characteristic time periods that are speeding up, or spatial scales that are expanding and synchronizing. An important component of scale-sensitive research is to explain how this occurs, and to develop new ways of modeling systems whose fundamental underlying structure is changing over time. The test of a good model may not be whether it is successful in predicting particular ecosystem-institutional interactions and consequences, but whether it helps in understanding the importance of changes in the structure of the system in question.

Because of problems crossing scales, the idea that we can identify a single good policy level to affect ecosystem properties loses credibility. By the time the dynamics of the drivers at one scale are estimated, policy scales at other scales may well have changed. It is also possible that cross-scale manipulation is too complicated or blunt an instrument anyway, as in the case where all natural resource change is driven by local terms of trade instead of international terms of trade, or similar. It is hypothesized in general that the cross-scale "pass through" varies according to the resource use activity itself, as well as its connectedness to macroscale drivers.

An important and overlooked discontinuity involves what economists might term price transmission elasticity for exogenous variables (Sutton and Webb 1988). For example, consider the case of the proposition that international agricultural prices determine a significant share of agricultural land use. To what extent, and through what mechanisms, do these prices pass through to the micro level? Is it true that all hierarchical systems conduct price signals with identical "resistance?" If not, what are the implications for using international prices as a driving force at the unit of production, i.e., land-use manager, scale? Most importantly, what makes different resource-use systems more or less permeable to such macroscale signals? How do these land-use system vulnerabilities vary through time?

In many models, markets are considered to be an "efficient" conductor of price signals, but that 
Fig. 2. Multiple scales of driving forces and proximate agents of change (adopted from Folke et al., 1998a).

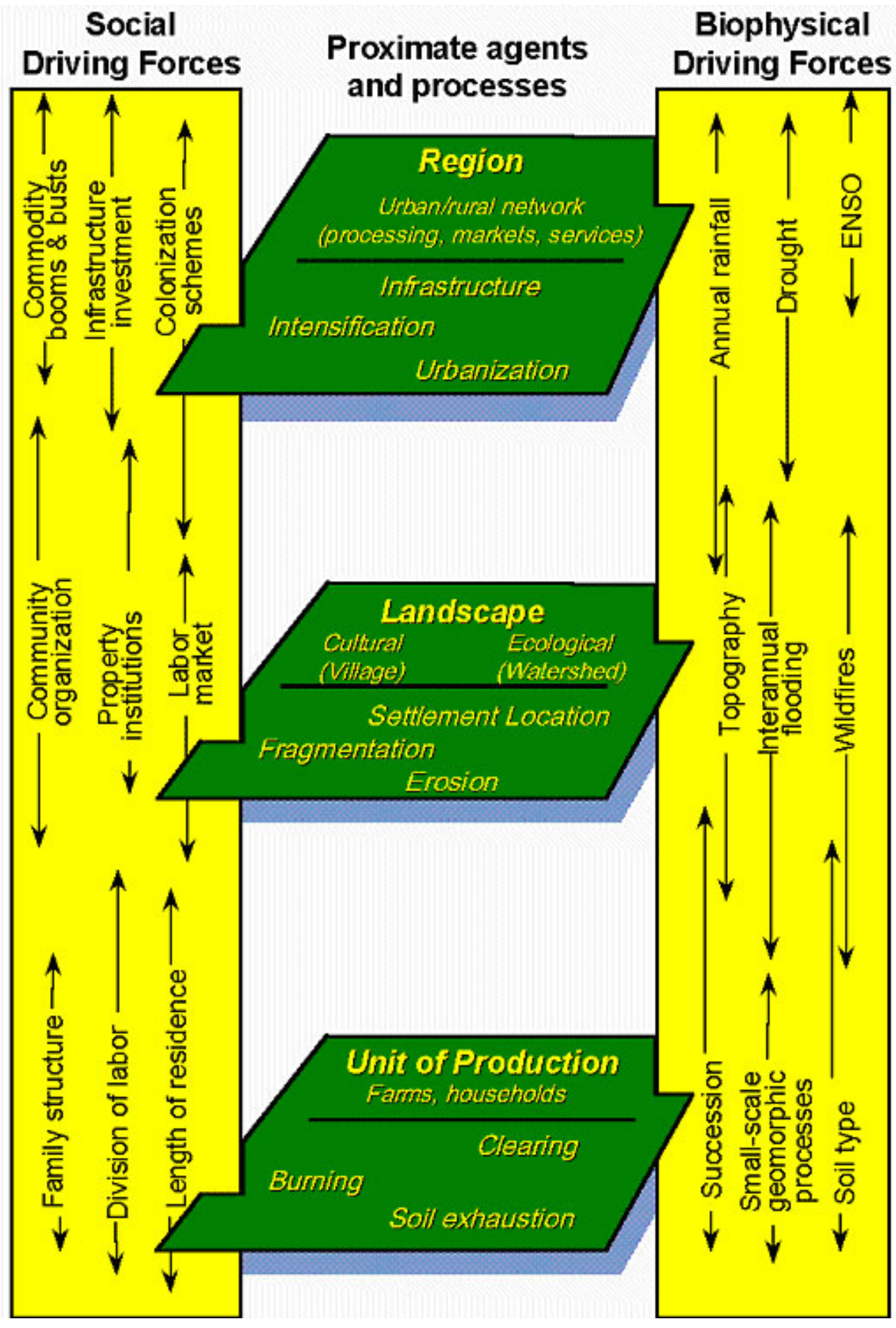


Table 1. Scales and the problem of fit (adopted from Folke et al. 1998a).

\begin{tabular}{ll}
\hline \hline Standard practice & Improved practice \\
\hline Abitrary (or even neglected) definition of scales & Empirical definition of scales, based on actual processes \\
Finding the "right" scale of analysis & Working at multiple scales \\
Alternating between scales of analysis & Demonstrating cross-scale linkages \\
$\begin{array}{l}\text { Hierarchy theory; scales are fixed, and are roughly } \\
\text { decoupled; larger, slower processes control smaller, faster } \\
\text { ones }\end{array}$ & $\begin{array}{l}\text { "Panarchy" theory; the scales of processes evolve over time, } \\
\text { newels emerge, some disappear; control may shift } \\
\text { between levels }\end{array}$ \\
\hline
\end{tabular}

conductivity is contextual and only dominant in certain property regimes. The important observation is that the transmission of prices is determined by the institutional setting, and, in agriculture, the institutions governing commodity trade often subvert, i.e., buffer, stabilize, or block, international price signals as they pass through to local markets. Moreover, even in relatively unprotected or exposed markets, where farm gate prices track international prices, decisions about production, consumption, exchange, and distribution are made by actors who, in turn, operate on a remarkably wide range of scales, from individuals/households to national and multinational firms, and through a broad palette of cultural diversity. In this way, signals on an international level may be propagated down to the farm level in complex pathways, with remarkably different effects (Sanderson and Pritchard 1998a).

This linkage is important for understanding the problem offitfor several reasons. First, just as there are clear mismatches between the scale and scope of ecological processes and the institutions that manage them, there are clear mismatches between the dynamics of external driving forces and the onthe-ground processes upon which they impinge. By their very nature, many of the driving forces are oneway, top-down forces that do not receive feedback from the consequences they engender. Second, the information that governs the dynamics of external drivers may be completely unrelated to their environmental and social impact; governments that set food price policy to satisfy the demands of urban factory workers may have little regard for the unintended impact in the countryside. Third, local institutions that govern local resource use respond to these external forces, either by evolving mechanisms for dealing with the uncertainty they introduce, or by organizing to confront and influence the larger-scale processes that govern them.

Obviously, the misfit of scales is central to the problem of fit within institutions and between ecosystems and institutions. Lee (1993) attributes the problem of overexploitation to a mismatch of scales: "when human responsibility does not match the spatial, temporal, or functional scale of natural phenomena, unsustainable use of resources is likely, and it will persist until the mismatch of scales is cured."

Spatial mismatches occur where the boundaries of management do not coincide with the boundaries of the ecological entity. The "problem of the commons" may be seen as a spatial one: The shepherd owns her individual animals but not the more extensive land that nourishes them and which is open to all. There is no system of rights and responsibilities that describes and manages how grazing is to take place and how it is to be sustained on the pasture as a whole. And even if it existed, how would it relate to the ecological dynamics of the pasture? The problem is one of getting the scales right in a dynamic and adaptive fashion; thus collective action hold a solution for the so-called problem of the commons.

Temporal mismatches are often discussed in reference to time horizons of planners and politicians, i.e., short, relative to environmental and social changes, i.e., long. Management myopia 
resulting from the rhythms of the electoral cycle is not limited to environmental issues; it pervades political economy and macroeconomics (Dornbusch and Edwards 1991). It is equally likely that temporal mismatches display the reverse problem, so that in rapidly changing environments social systems are slow to respond and are characterized by cultural inertia and organizational rigidity (Kuran 1988).

Functional mismatches are mismatches of scope. Resource users may have very specific desires from a highly complex ecosystem, and they may tend to focus their management actions narrowly, ignoring side effects. In the area of environmental regulation, bureaucratic micromanagement through commandand-control policies often causes unintended consequences, or drives the regulated user to search for loopholes. But control may be too broad as well as too narrow. Mismatches of scope mayoccur when too unwieldy a policy tool is used to manage fine details of a system, e.g., trying to control land use with a tax on an internationally traded commodity.

\section{Reflection}

Although multiscale phenomena were not invisible in the perspectives discussed in the mid-990s, the strong micro-macro connections were not really studied as such (e.g., Liljenstrom and Svedin 2005). During the last decade, the increased interest in networks and evolutionary processes involving such bundles of connectivity is a new and almost qualitative jump in the analysis. This has also had implications for new, emerging contemporary concepts that incorporate old ideas, such as adaptive governance (Dietz et al. 2003, Folke et al. 2005). Cross-scale interactions in systems of multilevel governance have also become a popular research topic in the last decade, but the problem of fit in relation to ecosystem dynamics and management at various scales still needs to be addressed.

\section{Responses to surprise}

One way of structuring an inquiry into human social and economic processes at multiple scales is with a typology of response to surprise. Gunderson et al. (1997) have already proposed a three-fold typology of surprise, which not surprisingly has different types of institutional responses.

Type I surprises are what Gunderson calls local surprises. They may be created by a narrow breadth of experience with a particular system, either temporally or spatially. Local surprises have a statistical distribution, and the normal response to these surprises is to form subjective probabilities and use new information to update them in a Bayesian fashion, although following Heiner (1983) we might guess that this is only appropriate for very simple environments. Based on these estimates, there is a wide range of adaptations to risk that are amenable to economic rationality on an individual level, including risk-reducing strategies and risk spreading or risk pooling across independent individuals. Type I surprises are manageable by individuals and associations of individuals. There is probably no collective action problem.

Adaptation-to-risk strategies fail when surprises are not local, or when individuals are not independent. Type II surprises (Gunderson's panarchy surprises) occur when there are crossscale interactions, such as when local variables coalesce to form a regional or global pattern, or when a process exhibits contagion, as with fire, insect outbreak, and disease. Unintended consequences resulting from the action of many individual agents is a Type II surprise. Individual responses are not generally effective, although there are special cases; for example, Coase's (1960) farmer and herder come to mind. Instead, individuals may act in concert, if appropriate institutions are available or are readily formed (McKean 1996).

The final class of surprise by definition precludes prediction: Type III surprises comprise true novelty, never-before-experienced phenomena for which strict pre-adaptation is impossible. However, it may be possible that some systems cope with Type III surprises better than others if they have developed mechanisms for reorganization, learning, and renewal (Holling and Sanderson 1996). Type III surprises are especially useful in revealing latent processes that are undiscovered in "normal" times. Douglass North (North 1993) has quoted Frank Hahn (1987) to say, "There is a continuum of theories that agents can hold and act upon without ever encountering events which lead them to change their theories. "Type III surprises may generate that kind of change, or at least reveal the latent mental models to researchers. Oliver Coomes has begun work with an Amazonian community whose blackwater (oligotrophic) tributary was captured by 
the main whitewater river in a single flood event that reconfigured the watercourse and changed the nature of the fishery. He has been able to observe differential success in adaptation in different communities based on preflood patterns of organization that before had seemed unimportant (discussed in Sanderson and Pritchard 1998b). However, success in coping may have more to do with the timing of the surprise than with overall societal flexibility.

\section{Reflection}

Responses to surprise lie basically in the policy domain. At the analytical level, a broad repertoire of such policy responses has been highlighted. What is fairly new during the last decade is the shift in the policy community toward a greater interest in adaptation in relation to the earlier focus of mitigation (Adger 2006). This is most clearly seen in the domain of climate change and has implications for research policy in terms of choosing which phenomena to be addressed. Interest in adaptation has also grown on a more general or sustainability level, as was seen in the UN Johannesburg Conference of 2002. This shift has also generated more interest in the subjects of resilience and vulnerability, in particular in the composite and complex sets of factors used for such analyses.

\section{MANAGEMENT PRACTICES AND SOCIAL MECHANISMS FOR ECOSYSTEM-INSTITUTIONAL FIT}

The lessons from the literature on common property resources indicate that local-level institutions can learn and develop the capability to respond to environmental feedbacks and surprises faster than do centralized agencies. Some of the most sophisticated local institutions are found in areas in which these systems have developed over a long period of time, on the order of hundreds of years. Examples include Spanish huertas for irrigation, Swiss grazing commons (Ostrom 1990), and marine resource tenure systems in Oceania (Johannes 1978). In other areas, successful institutions have evolved over a short period of time (in the order of one decade) in response to a natural resource crisis. An example is the Turkish Mediterranean coastal fishery in Alanya (Berkes 1992). Yet other systems have collapsed and recovered sometimes more than once (Berkes et al. 1989). Ostrom (1990) has derived what are by now well known design principles from studies of long-enduring institutions that seem to have been successful in managing resources in a sustainable fashion.

\section{Complex systems and local institutions}

The volume Linking Ecological and Social Systems: Managing Practices and Social Mechanisms for Building Resilience (Berkes and Folke 1998) seeks to integrate two streams of resource management thought that differ from the conventional approach to improve the fit between institutions and ecosystems. The first involves rethinking resource management science in a world of complex systems with nonlinear relationships, thresholds, uncertainty, and surprise, using a systems approach and adaptive management. The second involves rethinking resource management and social science by focusing on institutions, largely property rights institutions, and, in particular, common-property systems.

The combination of those two streams of resource management has resulted in new insights concerning social-ecological linkages that contribute to building the resilience of the combined socialecological system. These insights into the problem of fit were generated from 13 case studies from a diversity of ecosystems in different parts of the world, and from both traditional and contemporary societies (Berkes and Folke 1998).

\section{Reflection}

The last decade has seen a rapid increase in interest in complexity theory. However, the elements in the governance field using these complexity approaches still have to expand on the role of the local level as seen in a broader setting and interplaying against these grander macro-level phenomena. In particular, the need for this is evident in the area of policy implementation, in which our understanding is still not ripe enough to sufficiently guide these processes, as exemplified by the implementation of the EU Water Directive. One could say that, in the earlier phase, the "low-hanging fruits" of the complex-systems thinking tree were harvested. The more highly elevated fruits that remain challenge the capacity of the methodological toolbox and its applications. 


\section{Ecologically adaptive management practices}

First we identified a diversity of management practices based on ecological understanding and knowledge. The practices ranged from monitoring and managing specific resources to ecologically sophisticated practices that respond to and manage disturbance and build resilience across scales in complex ecosystems (Table 2). Such management practices include protection of certain species, stages in their life histories, and habitats; multiple species and multiple-scale management of ecosystem processes; temporal restriction of harvest; resource switching and rotation; management of different phases of ecosystem development; landscape patchiness; and whole watershed management.

The first five management practices in the table also exist in conventional management, but in contrast to conventional management there are in our case studies generally effective regulations, enforcement actions, and social sanctions associated with those practices. The other eight practices are rare or nonexistent in modern society, but they are very sophisticated from an ecosystem management perspective. For example, Chisasibi Cree hunters rotate trapping areas on a 4-yr cycle to allow populations of beaver to recover and seem to manage fish on a 5- to 10-yr scale and caribou on an 80- to 100-yr scale (Berkes 1998). Succession is managed in shifting cultivation systems such as the milpa system in tropical Mexico, in which agriculture is a sequential cropping of crops and noncrops (Alcorn and Toledo 1998). The smallscale movements of Sahelian herders are designed to mimic the variability and unpredictability of the landscape patchiness (Niamir-Fuller 1998). In ancient Hawaii, whole river valleys were managed as integrated farming systems, from the upland forest all the way to the coral reef (Costa-Pierce 1987). The Gitksan of British Columbia are concerned not only with the production of fiber over several square kilometers, but also with the maintenance of ecological processes involving soil bacteria at the spatial scale of a few square meters (Pinkerton 1998). Range reserves of African herders provide a "savings bank" of forage that serves as buffer to disturbance and surprise (Niamir-Fuller 1998). Sacred groves in India absorb disturbance by serving as fire breaks for cultivated areas and villages (Gadgil et al. 1998). Some nomads behave like a disturbance by following the migratory cycles of the herbivores from one area to another, contributing to the capacity of the semi-arid grasslands of Africa to function under a wide range of climatic conditions (Niamir-Fuller 1998).

Many of these management practices are in stark contrast to conventional resource management. They do not regard forests as a storehouse for timber, or oceans as standing stocks of fish populations. They understand that the resource is a part of the system and has to be managed as such. They monitor and interpret the dynamics of complex ecosystems to secure a flow of the resource.

\section{Reflection}

The ecosystem approach has gained momentum during the last decade and incorporates many of the practices addressed above. Such practices were further addressed in relation to living with complexity and change in Berkes et al. (2003). A lot of research has addressed the adaptive capacity of local groups to respond to change, an issue that seems to be ever more closely related to vulnerability and resilience in the face of altered disturbances and climate change (e.g., Adger et al. 2005). Over the past decade, our ability to carry out in-depth analyses had benefited greatly from the expansion of research capacity in many countries of the "South." Although our larger, international understanding of adaptive capacity is still not very strong, our knowledge in this area continues to increase bit by bit. This is another manifestation of the expansion of the knowledge society in which new globalization features are starting to be strongly enhanced, this time in the knowledge production field.

\section{Social mechanisms and institutions}

The management practices are linked to a diversity of social mechanisms and institutions. The sequence of social mechanisms was organized as a hierarchy that proceeds from ecological knowledge to underlying world views. Institutions, in the sense of rules-in-use, provide the means by which societies can act on their ecological knowledge and use it to produce a livelihood from resources and services in their environment. Both knowledge and institutions require mechanisms for cultural internalization, so that learning can be encoded and remembered by the social group. World view or cosmology gives shape to cultural values, ethics, and basic norms and rules of a society (Berkes and Folke 1998). 
Table 2. Ecologically adapted management practices and social mechanisms for resilience and sustainability (adopted from Folke et al. 1998a).

Management practices based on ecological knowledge
Monitoring resource abundance and change in ecosystems

Total protection of certain species

Protection of vulnerable life-history stages

Protection of specific habitats

Temporal restrictions of harvest

Multiple species management; maintaining ecosystem structure and function

Resource rotation

Succession management

Management of landscape patchiness

Watershed management

Managing ecological processes at multiple scales

Responding to and managing pulses and surprises

Nurturing sources of renewal

Generation, accumulation and transmission of ecological knowledge

Social mechanisms behind management practices
Reinterpreting signals for learning

Revival of local knowledge

Folklore/knowledge carriers

Integration of knowledge

Intergenerational transmission of knowledge

Geographical transfer of knowledge

Structure and dynamics of institutions

Role of stewards/wise people

Cross-scale institutions

Community assessments

Taboos and regulations 
Social and religious sanctions
Coping mechanisms; short-term responses to surprises

Ability to reorganize under changing circumstances

Incipient institutions

Mechanisms for cultural internalization

Rituals, ceremonies, and other traditions

Cultural frameworks for resource management

World view and cultural values

Appropriate environmental ethics

Sharing, generosity, reciprocity, redistribution, respect, patience, humility
The underlying question about the relationship between the cultural values espoused by a people and the way that these people interact with their environment is a form of an older question: What is the relationship between ideas, institutions, and the material conditions of existence (Jamieson and Lovelace 1985)? In the present paper, we abandon simple ideas of environmental or social determinism, and of human/nature independence, in favor of a co-evolutionary view of the origin and maintenance of ideas, institutions, resources, and societies. The biophysical world is not seen as a single strong determinant of social mechanisms, but neither is it passively molded by human ideas and actions, nor is it simply a backdrop against which the human drama unfolds.

Examples of social mechanisms include the hunter's guild of the Yoruba in Nigeria that functions as a knowledge carrier to maintain ancient traditions and indigenous ecological knowledge (Warren and Pinkston 1998). Reef and lagoon fishery management in Oceania show pervasive spatial ecological knowledge diffusion inferred through striking similarities in the management system across island groups (Johannes 1978). Various kinds of taboos are ecologically functional and have the potential to build resilience in ecosystems (Colding and Folke 1997, Gadgil et al. 1998). Many resources are not managed by numbers but through the social conduct (Acheson et al. 1998). Rituals help people remember the rules and interpret signals from the environment appropriately (Chapin 1991). The vanua concept in Fiji is an integrated human-nature concept that regards the land, water, and human environment as a unit, one and indivisible (Ruddle et al. 1992). Several such prescientific ecosystem concepts are known from Europe, North America, and Asia, as well as from throughout Oceania, where they have been well documented (Costa-Pierce 1987, Gadgil and Berkes 1991). They represent examples of how to manage the human inhabitants and natural resources of entire drainage basins.

Furthermore, some institutions seem to be able to produce rules that "kick in" following certain kinds of stresses. In both traditional societies and contemporary resource management, tighter management rules seem to emerge in some cases following an intensification of resource use or decrease in resource supply. Examples include the emergence of tightly regulated family-based hunting territories in the last 200 yr in James Bay in place of loosely regulated community-based territories (Berkes 1989), the emergence of a system of "cascading property rights" for water use in Florida in the droughts of the 1970s and 1981-1982 (Light 1983), and the incipient institution of the "sleeping territoriality" of some Pacific Islands, which serves as a blueprint of property rights that is activated when fisheries resources are becoming 
scarce (E. Hviding, personal communication). Such "latent functionality" is of great interest in terms of examining the adaptive capacity of institutions to resource and ecosystem change. It resembles the redundancy of biodiversity in ecosystems (Walker 1992), in which species that have no role in key structuring processes under normal conditions have the capacity to absorb disturbances that challenge the processes and functions of the system (Holling et al. 1995).

\section{Reflection}

Because the landscape is strongly impacted by cultural factors, it is important to understand these factors if we are attempting to assess the ways in which new phenomena may change the material "environmental" grounds for society. In this context, a lot of work on taboos and sacred areas has been carried out during the last decade, and our understanding of co-evolutionary social-ecological processes and the features of both traditional and contemporary societies has been enhanced. Progress has been made on issues related to collective and social memory, but findings in this area must be linked to ecosystem management. The challenges of climate change have sparked considerable interest over the last decade in integrated social-ecological studies of strongly connected complex systems. Earlier climate change was a dubious possibility, especially to nonscientists. Now it is high on political agendas as expressed, for example, in G8 priorities and similar measures.

\section{Responding to disturbance}

There are many examples of local communities that have recognized the necessity for the co-existence of gradual (exploitation and conservation phases) and rapid (release and reorganization) change as described earlier for the forest fires in ecosystems (see Fig. 1). We believe that in their institutions they have accumulated a knowledge base of how to respond to dynamic changes in ecosystems (Berkes and Folke 1998). Holling et al. (1998) argue that they have developed social mechanisms that interpret the signals of creative destruction and renewal of ecosystems and cope with them before they accumulate and challenge the existence of the whole community. Disturbance entered at smaller scales and could not be blocked out. The local institutions evolved so that renewal occurred internally while overall structure was maintained. It is important to stress that those management practices and social mechanisms did not develop because these local communities were unusually insightful or "noble". A major reason, we believe, was that they were not in a situation of choice. There were no capital markets or insurance mechanisms that could pay for a sudden loss in a resource flow. There was no technical equipment and no fossil fuelbased infrastructure to block out disturbance and mask ecosystem deterioration.

Presumably, the social mechanisms of Table 2 represent only a tiny fraction of existing humanenvironmental adaptations. The practices and mechanisms provide a reservoir of real world active adaptations that may be of value in designing for sustainability (Gadgil et al. 1993). Several of them prevent the buildup of large-scale crises. They allow disturbance to enter at a lower level and they build resilience, in contrast to resource management in large parts of contemporary society in which disturbance is actively blocked out and variability is reduced or eliminated.

The social-ecological practices, mechanisms, and principles identified in Berkes and Folke (1998) have the potential to improve conventional resource management by providing (1) insights for designing adaptive resource management systems that flow with nature; (2) novel approaches to forestry, agriculture, fisheries, aquaculture, and freshwater management; (3) lessons for developing systems of social sanctions and successful implementation and enforcement of sustainable practices; (4) the means to avoid surprises caused by conventional resource management; (5) experiences in managing fluctuations and disturbance; and (6) directions on how to build social-ecological resilience for sustainability.

\section{Reflection}

The issues raised above represent one of the major challenges for research on sustainability, i.e., how to stimulate the emergence of multilevel and adaptive management systems that can secure the capacity to sustain ecosystem services (Folke et al. 2005). The interplay between periods of gradual change and periods of rapid change is an area that still needs to be addressed. This area becomes especially important in a context of global change 
and highlights the need to not just adapt to disturbance as such, but to sustain the ingredients of social-ecological resilience that provide the sources for renewal, innovation, and development. The alternative is societies that are relatively inflexible when it comes to dealing with change; these are sometimes referred to as rigidity traps or poverty traps (Gunderson and Holling 2002).

\section{ADAPTIVE MANAGEMENT AND NESTEDNESS OF INSTITUTIONS}

Enhancing the resilience of ecosystems to disturbance will be increasingly important in the light of threats from global environmental change. Ecotechnology (e.g., Mitsch and Jörgensen 1989) and ecosystem restoration (e.g., Cairns 1995) are tools that have great potential to increase this buffer capacity. However, they will be difficult to implement if they have no social/institutional framework to act within.

\section{Adaptive management}

Flexible social systems that proceed by learningby-doing are better adapted for long-term survival than are rigid social systems that have set prescriptions for resource use. Integrative ecosystem management can proceed by a design that simultaneously allows for tests of different management policies and emphasizes learning-bydoing. Called adaptive management, this approach treats policies as hypotheses and management as experiments from which managers can learn (Holling 1978, Walters 1986). This means that we need to view the implementation of policy prescriptions in a different, more adaptive way that acknowledges the ever present uncertainty and allows participation by various stakeholder groups. Adaptive management views regional development policy and management as "experiments," in which interventions at several scales are made to achieve understanding and to identify and test policy options (Holling 1978, Walters 1986, Lee 1993), rather than as "solutions." Adaptive management effectively breaks down the barrier between research and management. As it proceeds in a stepwise fashion, responding to changes and guided by feedback from the ecosystem, it allows for institutional learning (Gunderson et al. 1995).

\section{Reflection}

Adaptive management in relation to the ecosystem approach has been on the table since the late 1970s, and has received widespread interest during the last decade. Some claim that it is a failure, because it hasn't worked well over the longer term, and therefore management should shift back to conventional approaches. We do not agree with this perspective for at least two reasons. The first is that the process of adaptive management, whether it is science-based with active adaptive management or more passive adaptive management like the one described in many local communities and traditional societies, triggers learning and stimulates selforganization toward ecosystem management. That has been observed in several case studies during the last decade (Berkes et al. 2003). Second, the reason for the observed failure may be because of a too narrow appreciation of the social dimension of ecosystem management, and this dimension is, as we have argued here, of great significance in relation to the problem of fit.

\section{Institutional learning and bounded rationality}

Understanding institutional learning, if it exists, requires an understanding of the evolutionary processes of institutions. Recent advances in cognitive science have again highlighted the importance of bounded rationality in the development of human institutions (reviewed in Conlisk 1996). North has recommended this literature to economists because of the new frontiers it opens up for understanding institutions and bounded rationality (North 1993). The distinctiveness of the bounded rationality literature is its focus on imperfect rationality rather than imperfect information (Day and Pingle 1991), i.e., the deliberation cost problem as distinct from the transaction cost (Coase 1960) or the information cost problems (Conlisk 1996). Bounded rationality is appealing in that it adheres to an economic notion for its explanation of institutional behavior, i.e., the notion that human cognition is scarce and therefore costly. It explicitly acknowledges, in contrast to perfect rationality constructs, that the environment in which humans operate is complex and poorly understood.

One example of the importance of boundedly rational behavior in the evolution of institutions relies on the notion of a competence-difficulty gap. 
Ronald Heiner (1983) argues that the origin of predictable, or rule-bound, behavior, such as an institution, is not in situations in which human agents model their environment well, but in those situations in which there is a high level of uncertainty. Under certain conditions, a higher degree of flexibility increases the probability of making costly mistakes in comparison with abiding by the rules of an institution. In Heiner's formulation, humans add behaviors to their repertoire under the condition that they can choose when to use them reliably. Unreliability comes from environmental complexity and human fallibility in perception and in decision making. Heiner thus proposes a way to answer the following kinds of questions:

- When will a person (or group) decide to be behaviorally responsive to environmental information, and when will they decide to be unresponsive?

- When is the right time to search for more information?

- When is it the right time to learn?

Note that Heiner's argument is not that institutions evolve to reduce uncertainty, although that is a second-order effect, but rather that they evolve in response to uncertainty, because humans are unable to respond optimally to numerous and hopelessly complex sets of relationships. At least some of these institutions result not from a sophisticated understanding of the environment, but from our inability to cope with its complexity. The implication is that there are times when more and more information is not useful, and that simple heuristics, myths, or institutions are more beneficial on average in structuring behavior.

The theory thus encompasses at least one form of irrational behavior, the problem of time inconsistency. It has been suggested that, when individuals know that they will be tempted to act against their own self-interest by attending to the wrong signals, they will engage in binding behavior, e.g., an alcoholic may determine in advance to take a drug that makes him physically ill when consuming alcohol. Such behavior is a determination to focus on longer-time-scale information, such as the state of his health, which varies more slowly than the short-time-scale temptation or the euphoria that comes from having a drink. Behavior that is more flexible may not be more fit if there is the potential for time inconsistency. Rigid behavior is more adaptive in this case. It is reasonable to assume that certain natural resource institutions perform the same role at times by mitigating the temptation to overexploit a resource.

Heiner's theory also helps to explain why individuals and, by extension, societies would rationally resist evidence and persist in conservative behaviors. Heiner refers explicitly to the punctuated equilibrium literature, and especially to Kuhn's discussion of the discontinuous process of paradigm change (Kuhn 1962), in pointing out that the lack of (Heinerian) reliability will cause scientists to resist new theories and to systematically ignore accumulating evidence. This may have been the case in the collapse of the Newfoundland codfisheries described by Finlayson and McCay (1997). Inshore fishers, who had traditionally seen failures in the fishery as natural and transient, began to realize, when the offshore fishery escalated, that failure could be caused by fishing itself. The irony of the case is that the inshore fishers were unable to convince managers and scientists of the impending crisis; managers and scientists were preoccupied with the offshore fishery and completely missed the signals that the inshore fishers were learning from until the entire stock had collapsed. Institutional learning through adaptive management may indeed require a crisis.

\section{Reflection}

Institutional learning, which might perhaps be better described as collaborative and collective learning that becomes embedded in institutions, has increased in importance during the last decade. Because of the ability of institutions and organizations to incorporate learning into management, they have progressed from adaptive management to adaptive co-management, (e.g., Olsson et al. 2004a, Armitage 2005, Imperial 2005), which deliberately connects varied governance structures into more intentional structures. From coadaptive management they moved on to the even broader concept of adaptive governance that now covers the interplay among governance systems over a broad range of multilevel organizations in relation to ecosystem management and services (Dietz et al. 2003, Folke et al. 2005). The investigation into these normative and administrative 
settings is just now getting under way. This is a change from research capacities and interests in the mid-1990s.

\section{Nested institutions}

Narpat Jodha sees resource management systems that are directly, totally and, crucially dependent on local resources, with close proximity to and intimate knowledge of the resource base and associated with closed or isolated situations, as being "ecologydriven" (Jodha 1995). For Jodha, fit is a function of proximity, physical and economic, to the resource base and isolation from other influences. By implication, he is saying that only when it is isolated, closed, and dependent on resources does traditional ecological knowledge evolve and persist. We challenge this perspective below, with the observation that broader institutions are not only politically and economically probable, but that they may be able to negotiate a better fit to broader and slower biophysical attributes of the system as well.

A more general question is posed: What are the ways in which local resource management can be coupled to larger-scale institutions without losing their local fit to the resource base? How can states and national governments be coupled to resource users in nondisruptive ways? One answer we propose is the so-called "tenurial shell" (see below). Another answer, which we note but do not explore in this paper, sees indigenous agents in their role of resisting hierarchical control and seeking accommodation with large-scale power structures from a position of at least limited power, at various times either helped or hindered by the international community (Taussig 1987, Peluso 1992, Tsing 1993).

As we stressed earlier, the institutions of conventional (read "modern") resource management have been successful in producing yields and economic growth in the short term, but have not been very successful in safeguarding the dynamic capacity of ecosystems or in managing socialecological systems for resilience and sustainability. In building centralized bureaucracies for environmental management over the years, it has been assumed that resource management can be scaled up. That does not seem to be the general case.

Understanding the failure of centralized bureaucracies is a fundamental task in analyzing ecosystem- institutional linkages and must be viewed historically. What is the result of the commercialization of agriculture, the integration into the market, and the penetration of centralized administration on all forms of "middle management" by human institutions? What forms does the political integration process take; when and how does the state replace or alter local community institutions? For many developing countries, this process has gone on in precolonial, colonial, and national periods, with different forms of state authority affecting local management institutions in different ways.

However, all centralized management institutions could not be replaced by community-level institutions. That would be to assume that resource management could be scaled down. The evidence from various case studies supports the proposition by Holling et al. (1998) that environmental and renewable resource issues tend to be neither smallscale nor large-scale but cross-scale in both space and time. It follows therefore that the problems have to be tackled simultaneously at several levels. Thus the power of centralized management agencies should not be eliminated but should be partly redistributed to local-level institutions and balanced, not eliminated. Management power and responsibility should be shared cross-scale, among a hierarchy of management institutions, to match the cross-scale nature of management issues.

Holling and Sanderson (1996) present attributes of institutions in different phases of institutional development. Centralized management institutions seem increasingly to dominate in the development phase from innovation to consolidation, although they seem to play a less importance role in the phases of release, renewal, and transformation (Schumpeter 1950; Table 3). A fundamental mechanism enhancing the resilience of natural and social systems alike is variability and adaptation through renewal. Opportunities for periodic reshuffling within institutional levels seem to maintain the adaptive opportunity for renewal. The institutional capacity to maintain opportunity for renewal within and between social and ecological systems may be particularly important on the regional and global scale, if we are to cope successfully with planetary or climatic stresses.

Local institutions may play an important role in monitoring and responding to ecosystem change, as we have shown above, but they will never be 

yesterday"

"Inventing

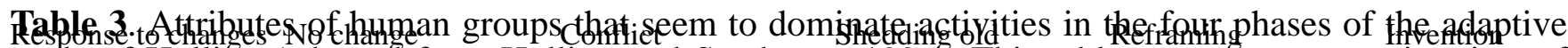
cycle of Holling (adopted from Holling and Sandersomeh 296 is This tablestrapresents a centrist view of primarily North American institutions.

\begin{tabular}{|c|c|c|c|c|c|}
\hline Time horizon & $\begin{array}{l}\text { Time of office } \\
\text { (linear time) }\end{array}$ & $\begin{array}{l}\text { Present } \\
\text { (discontinuous) }\end{array}$ & $\begin{array}{l}\text { Time out } \\
\text { (multiple scales) }\end{array}$ & $\begin{array}{l}\text { Near future Distant fu } \\
\text { (multiple scales) }\end{array}$ & uture \\
\hline Space horizon & $\begin{array}{l}\text { Building and } \\
\text { holding bounds }\end{array}$ & $\begin{array}{l}\text { Destruction } \\
\text { of old bounds }\end{array}$ & $\begin{array}{c}\text { PhaseSofspedeptönecefycle } \\
\text { boundaries }\end{array}$ & Creating new bounds & \\
\hline Attribute & $\mathrm{r}$ to $\mathrm{K}$ & $\mathrm{K}$ to $\Omega$ & $\Omega$ to $\alpha$ & $\alpha$ to $r$ & A to exit \\
\hline Nature of truth & Constructed & Challenged & Deconstructed & Reconfiguring & New myths \\
\hline and reality & & & & myths & (visionary) \\
\hline
\end{tabular}

effective unless they are connected to larger institutions in a way that permits flexibility, adaptability, and resilience. For example, to survive, the locally adapted social-ecological systems analyzed in Berkes and Folke (1998) need to be protected, but not isolated, from external driving forces such as macro-economic and trade policies, which may not be uniformly appropriate for all local systems. Such support can be provided by umbrella institutions such as the tenurial shell for local community forest management created by the Mexican state (Alcorn and Toledo 1998), or through nested sets of institutions (Ostrom 1990, Hanna et al. 1996). Such nested systems of governance exist, for example, in the comanagement process in Maine's soft-shell clam fishery for the sharing of rights and responsibilities between the State of Maine and the local community (Hanna 1998).

Nestedness does not necessarily imply a top-down hierarchical structure. In governance terms, microphenomena such as the choice of lifestyle can have a strong accumulated macro-effect, and the core causality might be difficult to trace to one level or the other. There are synergy effects drawing on sources from many levels simultaneously, i.e., the effects are contextual.

Nestedness does not imply tight links. There may be loose coupling, in the sense that local communities only communicate a small set of information to the higher-level institution. According to Holling and Sanderson (1996), such loose coupling allows a wide latitude for experimentation within levels. However, experimentation requires that the ecosystem has not been seriously reduced. In that case, experimentation may cause threshold effects. Knowledge of the dynamics of complex ecosystems is therefore of great importance (Berkes and Folke 1998). Until modern human institutions are responsive to ecosystem dynamism and designed to flex with natural variability, their principle impact will be to impede nature, not to sustain the lifesupport system on which they depend.

What this suggests is that policy and institutional building should be concerned with more than the immediate consequences of incremental actions. It should recognize the potential for an accumulation of small actions, each on their own perhaps quite harmless, to destabilize important natural and social systems. The difficulty is that, although we can predict with reasonable confidence the immediate consequences of an incremental action, we cannot predict the consequences of an entire sequence of actions without understanding the systems potentially being affected by them (Levin et al. 1998).

\section{Reflection}

Although the cross-scale investigations may have been taking place in the 1990s at an analytical level, what is now emerging is a stronger understanding that the interlinkages between the socioeconomiccultural spheres and the ecological ones are not only analytical in nature but real. This calls for yet another higher level of analysis of which the interconnected system, rather than the relationship between two systems, is the core object, which would entail an analysis of the fit between them. In this context, work on leadership, team building, social networks, the emergence of organizations, the roles of actor and actor groups, etc., becomes of high relevance for understanding processes of adaptive governance and adaptive capacity during 
periods of abrupt change and reorganization (Gunderson and Holling 2002, Folke et al. 2005). Researchers must also try to determine which of the multitude of links are tight couplings and which are less so (Levin 1999). The understanding of this distinction also holds the key to the systems characteristics of the joint system. Here the past decade has seen some very interesting approaches, e.g., in archeology, that have used complex systems theory to develop understandings about the longterm development of societies and their potential rapid transitions (e.g., van der Leeuw 2000).

\section{RESEARCH CHALLENGES FOR THE PROBLEM OF FIT BETWEEN ECOSYSTEMS AND INSTITUTIONS}

Clearly, conventional approaches will not suffice to cope with the spectrum of potentially catastrophic and irreversible environmental problems caused by loss of biodiversity and ecosystem resilience. According to Levin et al. (1998), these problems are characterized by their unpredictability, i.e., surprise is to be expected; by the potential importance of thresholds and domain shifts; by the difficulty of detecting change early enough to allow effective solutions or even to develop scientific consensus on a time scale rapid enough to allow effective solution; and by the likelihood that the signal of change, even when detected, will be displaced in space and time from the source, so that motivation for action is small. Conventional market mechanisms will be inadequate to deal with these problems. Response systems and institutions that are flexible and adaptive are needed.

How can we stimulate the development of institutions that respond to environmental feedbacks and that safeguard the capacity of ecosystems to generate essential resources and ecosystem services? There must be social mechanisms in a society by which information from the environment may be received, processed, and interpreted to build the resilience of the linked social-ecological system. At present, there is a pervasive lack of social response mechanisms for dealing with changing environmental conditions. Needed are institutions that are in tune with the functions of ecosystems and the natural resources and ecological services that they generate at multiple scales. What are the prospects for making this happen?
A major challenge concerning the problem of fit is to build institutions that monitor ecosystem change and that generate, accumulate, and transfer ecological knowledge and understanding. A new concept of management must provide for actions that nurture rather than constrain variability, and that allow disturbance to enter at scales that do not disrupt ecosystem performance and resilience.

Obviously, the list of issues that need to be addressed for improving the institutional-ecosystem fit is almost infinite. In the following, we suggest a few lines of inquiry with the potential to improve the understanding of these relationships. A great deal of prior research has focused on the structure of ecosystems or the structure of institutions. We consider the dynamics of institutional change and their relation to ecosystem change and resilience to be the interesting issues.

\section{Monitoring, communication, and indicator building}

An important set of questions surrounds the social relations of monitoring, detection, and communication of environmental signals.

- Which stakeholders monitor which kinds of environmental signals? How is the responsibility for monitoring spread across stakeholders?

- What environmental signals are systematically ignored and why? This question is as important as what signals are attended to; see Heiner 1983).

- What kinds of change are monitored for important environmental signals? Are levels monitored, or their variability, or the potential for sudden or irreversible change? Each of the kinds of monitoring can imply different sorts of institutional responses. Changes in the levels of resource stocks or flows may result in changes in levels of hunting or harvesting pressure, whereas changes in variability will affect forms of risk management, and the threat of collapse may induce more fundamental institutional restructuring.

- Who has social standing to report 
environmental information, and who may interpret it? Who has the power to act? Environmental signals must be passed from monitors to actors, and information can be lost, twisted, amplified or attenuated in the process.

- What sorts of ecosystem signals are used or are potentially useful as indicators of significant environmental change? With this question there are opportunities to link to existing international programs to develop indicators of environmental change for policy-making purposes. By considering the role of indicators and their theoretical connection to institutions, it may be possible for the policy community concerned with indicators to engage social scientists with a wide breadth of experience in linked socialecological systems, and vice versa.

\section{Measuring the scale of an institution}

How can the scale of an institution be measured? Institutions have multiple attributes, as do the ecosystems they govern, and these may not necessarily operate at similar scales. Property rights, for example, may be classified in many ways, and each leads to a different measure of scale and a different interpretation of institutional fit (Hanna et al. 1996). This is illustrated by the following questions about a property right inspired by Parker Shipton (1988):

- Right to what? What resource or ecosystem attribute is the right over? What is the valuable property in question, and what are its spatial and temporal scales? This is essentially an ecological question.

- $\quad$ Right for what? What are the legitimate uses or actions that are permitted relative to the resource? Shipton recognizes rights of use, transfer, and administration. This is a question of functional scale or scope.

- For how long? The temporal scale of the right includes the customary length of tenure, which may be for a season, for a lifetime, or until some specified conditions hold. There are several attributes that will govern the temporal scale of the right, relating to the time scale of the resource (life-span, rates of movement), the period of tenure (allowable season of harvest, life-span of the holder), and the time scale of the right guarantor.

- For whom? Who holds the right? Who could potentially hold the right? Is it an individual or a collectivity? How is the collective specified? This is a question of scale also, as measured by numbers of actual and potential stakeholders, or by the territory that they occupy.

- Against whom? Who is excluded from using the resource because of the property right? As for (d) above, this is also a question of scale.

- Upheld by whom? Who guarantees that the right may be exercised and that others may be excluded? The spatial scale of the guarantor is most probably specified by political rather than ecological boundaries.

\section{Understanding resilience in ecosystems and institutions}

It is not at all clear that robustness or resilience in institutions is always a good thing. Maladaptive but resilient institutions can allow poor environmental management to persist for very long periods of time, particularly if such institutions are subsidized by other social or economic sectors, or if they are operating at the wrong scale.

How is institutional resilience defined and measured? How can institutional resilience be monitored? What are key indicators?

When is institutional resilience a bridge or a barrier to ecosystem resilience? In any particular situation, is institutional robustness consonant with sustainable outcomes?

How are different institutional structures and property rights regimes linked to incentives facing various users? For example, which attributes of 
property rights systems promote the resilience of both the ecosystems and the institutions, and in different phases of development? Which retard resilience?

What is the role of scale in maintaining institutional and ecosystem resilience? What mechanisms maintain the resilience of linked and also nested institutions? When do signals of ecosystem change flow through a nested set of institutions, loosely coupled or strongly coupled? How can environmental information be effectively communicated across institutional levels or windows of opportunity?

\section{Understanding the evolution of institutions}

It is a gargantuan task to catalog land-use practices, property rights, and cultural norms that appear well adapted to their environmental and social contexts. Future research must tease apart the true adaptive significance of these institutions, as well as assess their vulnerability to change or collapse. None of these institutions are timeless or ahistorical; rather they are dynamic, variable, historically contingent, and possibly unpredictable. These evolutionary properties, although perhaps debilitating to prediction, will allow scholars to understand where claims of fit are real and where they are spurious.

In terms of social mechanisms, how do institutions arise that govern the use of natural resources? The question of origin is interesting in its own right, because frequently descriptions of adaptive institutions are overly static. The collective action problem applies both to the origin and maintenance of institutions, and different rules may govern the two processes. Understanding the conditions under which institutions arise and how the historical development of institutions influences their current state will help to transcend the functionalist fallacy. In this way, current sets of institutions will not necessarily be seen as optimal a priori, but rather will be understood to be a product of historical events, accidents, and past environment. Observing the evolutionary process of making, breaking, modifying, and abandoning rules can make possible a strong demonstration of institutional fit. In this context the important question should be analyzed: How can institutions be developed that promote disturbance to enter instead of continuously striving towards reducing variability?

How does rule switching take place? Is switching active or passive? What are the mechanisms for maintaining and sporadically unleashing latent functions such as sleeping territoriality? What determines whether switching occurs or minor incremental adjustment occurs? Does a switch occur because of a discrete choice, i.e., there are limited alternatives, or is a hard switch an example of a bang-bang optimal control for resource management (Clark 1990)?

What are the kinds of changes that Traditional Ecological Knowledge (TEK) can withstand, and to what kind of changes is it most vulnerable? Like keystone processes for ecosystems, are there keystone norms and rules that keep institutions resilient? If so, how do they relate to ecosystem resilience? What is the role of TEK in this context?

What is the turnover time of folklore and folk traditions? How are outdated institutions replaced? When is institutional inertia a stabilizing force, and when does it become a destabilizing rigidity? When is institutional resilience in conflict with ecosystem resilience? What does durability of institutions under changed environmental conditions mean? Is there an adaptive role to institutional memory?

\section{Avoiding functionalism in the analysis of fit}

How does one avoid a nä̈ve functionalism with respect to cultural practices that have an environmental effect? Is it possible to tease apart those aspects of institutions that are purposive and active from those that are merely responses to social-ecological opportunities or to environmental constraints? It will not be expected that the same balance between purpose and response obtains in every environmental context. For example, in the practice of field scattering, in some contexts this may be a risk management strategy, whereas in others it may be merely the result of a constrained land market under conditions of multiple inheritance (McCloskey 1991, Goland, 1993). Although some taboos have conservation implications, that is not true for all taboos (Hames 1991), and concepts for distinguishing them are necessary (Colding and Folke 1997) Where are they adaptive, and where not? For example, when scarce resources become suddenly abundant, are there rules for how to relax taboos? Under what circumstances does such a rule about rules arise?

How is evidence of institutional convergence to be judged? With regard to what resources are there the strongest examples of convergence in institutional 
structure? Is finding the same solution in different circumstances stronger evidence for the functional significance of environmental institutions?

\section{Governance and conflict}

How do we design dynamic institutions that account for the flows and feedback between systems and that maintain the resilience needed to ensure a continuation of these flows? Many ecologists argue that a watershed or drainage basin is a rational biophysical/ecological selection of a specific space as a system boundary (Naiman 1992, McDonnell and Pickett 1993). Generally, the boundaries between institutional/governance areas and the watershed area do not correspond. There is an environmental-institutional conflict. Just as there are often many countries in a drainage basin, there are often different institutional, jurisdictional, and administrative settings also within subdrainage basins. One reason for the mismatch is that the institutional/governance realm was developed for other purposes in history than to match with the biophysical/ecological area. Classic reasons for the selection of an observed system of governance are national security or ethnic specificity.

On the other hand, when is it adaptive for governance systems not to coincide with ecological systems? When would too tight a fit result in environmental degradation over all rather than just a part of an ecological system? How does this process help at time to delink ecosystems from political processes and time scales?

As Lee (1993) notes, most environmental choices entail potential conflict because they involve the redistribution of rights and opportunities. Institutional change with respect to environmental resources frequently arises as those impacted by negative externalities demand compensation for losses incurred. The fundamental lack of fit in this case is between agency and impact, between those who benefit and those who bear the cost. How do institutions that have evolved to deal with social conflict affect environmental outcomes? What are the environmental side effects of choices regarding the distribution of rights and resources?

Lee's other fundamental factor leading to conflict is uncertainty; the properties and behavior of natural systems are not well understood. Part of this is inherent in the complexity of the ecological world, and part is because of the lack of fit between monitoring institutions and the resources they seek to understand, as when political boundaries cut across natural ecological boundaries such as watersheds. Further, data are scarce and difficult to interpret, so it may be impossible to choose between competing hypotheses that have starkly different management implications (Wilson et al. 1990). When such a situation occurs, there is a great deal of room for human conflict. The battle over conceptual models may assume a strategic role, and the obfuscation and repression of knowledge may become a source of political advantage for privileged groups (Lindblom 1990, Holling and Sanderson 1996).

\section{Envisioning institutional futures}

What are the likely trajectories of change in human institutions pertaining to the environment? Are there secular trends toward intensification of land-use systems and attendant shifts toward individualization and/or privatization of property rights (Netting 1993)?

What changes are likely under conditions of climatic change, increasing climatic variability, ecosystem fragmentation, etc.? Can predictions be made about the role of global change on management institutions in particular contexts?

What are the forces that maintain a mismatch between institutions and their environment?

What is the role of major international players such as multinational companies, the World Trade Organization, financial markets, etc., in reducing or building social-ecological resilience? What are their responsibilities legally, morally, and ethically? What do the feedbacks from larger institutions to ecosystems and back to local institutions look like? Is the lack of fit strengthened by increasing trade and opportunities for economic growth that can cause environmental effects that spread over larger and larger geographical areas (Ekins et al. 1994, Anderson et al. 1995)?

What is the role of internationalization and globalization for ecosystem-institutional fit? Is there a role for international agreements to promote ecosystem-institutional fit? How can environmental agreements be given "teeth" to have a word in global development issues? 


\section{Reflection}

This comment is the final one and tries to sum up some of the comments about the emerging field we have discussed. We try to point to a few domains of future investigation that may be of great importance but remain poorly studied. As we have seen during our comparisons step by step in the text above, the following 10 points would be worth looking into:

1. The development of complex systems theory to be applied to integrated social-ecological systems, including the economic and cultural domains. This includes the extent to which both partial systems and the total system can be described as nested. It also means that the idea of fit between the parts is hereby transformed into an issue of the behavior of the system as a whole;

2. The investigation into the development and evolution of norms in relation to adaptive capacity for dealing with change;

3. New understanding of the economic drivers operating at multiple levels simultaneously as part of a governance system and in the context of globalization.

4. New perspectives on global societal dynamics in relation to the dynamics of the biosphere.

5. New societal understanding about the roles of technology and knowledge in the interplay with the socioeconomic-cultural and environmental systems.

6. More insight into the vulnerability and resilience facets and what this means in terms of policy design.

7. A broader sense of what are to be interpreted as "institutional factors" in the context of adaptive governance, which could include various facets of governance, networks, leadership, and actor groups.

8. The consequences of a stronger emphasis on dynamics when entities that are changing their relations also are undergoing internal transformations. The network aspects of these relations are here a part of the challenge;
9. The roles of information and knowledge in relation to the broader societal change and resilience factors at various levels;

10. The features of transitions, tipping points, or threshold conditions in the integrated system and how they operate across various levels.

Responses to this article can be read online at: http://www.ecologyandsociety.org/voll2/iss1/art30/ responses/

\section{LITERATURE CITED}

Acheson, J. M., J. A. Wilson, and R. S. Steneck. 1998. Managing chaotic fisheries. Pages 390-413 in F. Berkes and C. Folke, editors. Linking social and ecological systems: management practices and social mechanisms for building resilience. Cambridge University Press, Cambridge, UK.

Adger, W. N. 2006. Vulnerability. Global Environmental Change 16:268-281.

Adger, W. N., T. P. Hughes, C. Folke, S. R. Carpenter, and J. Rockström. 2005. Socialecological resilience to coastal disasters. Science 309:1036-1039.

Alcorn, J. B., and V. M. Toledo. 1998. Resilient resource management in Mexico's forest ecosystems: the contribution of property rights. Pages 216-249 in F. Berkes and C. Folke, editors. Linking social and ecological systems: management practices and social mechanisms for building resilience. Cambridge University Press, Cambridge, UK.

Allison, H. E., and R. J. Hobbs.2004. Resilience, adaptive capacity, and the "lock-in trap" of the Western Australian agricultural region. Ecology and Society 9(1): 3. [online] URL: http://www.ecol ogyandsociety.org/vol9/iss1/art3/.

Andersson, T., C. Folke, and S. Nyström. 1995. Trading with the environment: ecology, economics, institutions and policy. Earthscan, London, UK.

Armitage, D. 2005. Adaptive capacity and community-based natural resource management. 
Environmental Management 35:703-715.

Arthur, W. B. 1994. Increasing returns and path dependence in the economy. University of Michigan Press, Ann Arbor, Michigan, USA.

Baskerville, G. 1995. The forestry problem: adaptive lurches of renewal. Pages 37-102 in L. H. Gunderson, C. S. Holling, and S. Light, editors. Barriers and bridges to the renewal of ecosystems and institutions. Columbia University Press, New York, New York, USA.

Behnke, R. H., Jr., I. Scoones, and C. Kerven, editors. 1993. Range ecology at disequilibrium: new models of natural variability and pastoral adaptation in African savannas. Overseas Development Institute, London, UK.

Bellwood, D. R., T. P. Hughes, C. Folke, and M. Nyström. 2004. Confronting the coral reef crisis. Nature 429:827-833.

Berkes, F. 1992. Success and failure in marine coastal fisheries of Turkey. Pages 161-182 in D. W. Bromley, editor. Making the commons work. Institute for Contemporary Studies, San Francisco, California, USA.

Berkes, F. 1998. Learning to design resilient resource management: indigenous systems in the Canadian subarctic. Pages 98-128 in F. Berkes and C. Folke, editors. Linking social and ecological systems: management practices and social mechanisms for building resilience. Cambridge University Press, Cambridge, UK.

Berkes, F., editor. 1989. Common property resources: ecology and community-based sustainable development. Belhaven, London, UK.

Berkes, F., J. Colding, and C. Folke, editors. 2003. Navigating social-ecological systems: building resilience for complexity and change. Cambridge University Press, Cambridge, UK.

Berkes, F., D. Feeny, B. J. McCay, and J. M. Acheson. 1989. The benefits of the commons. Nature 340:91-93.

Berkes, F., and C. Folke. 1994. Investing in cultural capital for a sustainable use of natural capital. Pages 128-149 in A. M. Jansson, M. Hammer, C. Folke, and R. Costanza, editors. Investing in natural capital: the ecological economics approach to sustainability. Island Press, Washington, D.C., USA.

Berkes, F., and C. Folke, editors. 1998. Linking social and ecological systems: management practices and social mechanisms for building resilience. Cambridge University Press, Cambridge, UK.

Berkes, F., T. P. Hughes, R. S. Steneck, J. A. Wilson, D. R. Bellwood, B. Crona, C. Folke, L. H. Gunderson, H. M. Leslie, J. Norberg, M. Nyström, P. Olsson, H. Österblom, M. Scheffer, and B. Worm. 2006. Globalization, roving bandits, and marine resources. Science 311:1557-1558.

Bromley, D. W. 1991. Environment and economy: property rights and public policy. Basil Blackwell, Oxford, UK.

Brown, K. 2003. Integrating conservation and development: a case of institutional misfit. Frontiers in Ecology and the Environment 1:479-487.

Cairns, J. 1995. Rehabilitating damaged ecosystems. CRC Press, Boca Raton, Florida, USA.

Carpenter, S. R., and W. A. Brock. 2006. Rising variance: a leading indicator of ecological transition. Ecology Letters 9:311-318.

Cash, D. W., W. N. Adger, F. Berkes, P. Garden, L. Lebel, P. Olsson, L. Pritchard, and O. Young. 2006. Scale and cross-scale dynamics: governance and information in a multilevel world. Ecology and Society 11 (2): 8. [online] URL: http://www.ecolog yandsociety.org/vol11/iss2/art8/.

Chapin, M. 1991. Losing the way of the Great Father. New Scientist (August 10):40-44.

Clark, C. W. 1985. Bioeconomic modelling and fisheries management. John Wiley, New York, New York, USA.

Clark, C. W. 1990. Mathematical bioeconomics. John Wiley, New York, New York, USA.

Clark, W. C. 1987. Scale relationships in the interactions of climate, ecosystems, and societies. 
Pages 337-378 in K. C. Land and S. H. Schneider, editors. Forecasting in the social and natural sciences. Reidel, Dordrecht, The Netherlands.

Clark W. C., J. Jäger, J. van Eijndhoven, and N. Dickson, editors. 2001. Learning to manage global environmental risks: a comparative history of social responses to climate change, ozone depletion, and acid rain. MIT Press, Cambridge, Massachusetts, USA.

Clark, W. C., and R. E. Munn, editors. 1986. Sustainable development of the biosphere. Cambridge University Press, London, UK.

Coase, R. 1960. The problem of social cost. Journal of Law and Economics 3:1-44.

Colding, J., and C. Folke. 1997. The relations among threatened species, their protection, and taboos. Conservation Ecology 1(1):6. [online] URL: http://www.consecol.org/vol1/iss1/art6/.

Conlisk, J. 1996. Why bounded rationality? Journal of Economic Literature 34:669-700.

Costa-Pierce, B. A. 1987. Aquaculture in ancient Hawaii. BioScience 37:320-331.

Costanza, R., and C. Folke. 1997. Valuing ecosystem services with efficiency, fairness and sustainability as goals. Pages 49-68 in G. Daily, editor. Nature's services: societal dependence on natural ecosystems. Island Press, Washington, D. C., USA.

Costanza, R., B. S. Low, E. Ostrom, and J. Wilson, editors. 2001. Institutions, ecosystems, and austainability. Lewis, Boca Raton, Florida, USA.

Costanza, R., L. Waigner, C. Folke, and K.-G. Mäler. 1993. Modeling complex ecological economic systems: toward an evolutionary dynamic understanding of people and nature. BioScience 43:545-555.

Crutzen, P. J., and E. F. Stoermer. 2000. The "Anthropocene." Global Change Newsletter 41:12-13.

Daily, G., editor. 1997. Nature's services: societal dependence on natural ecosystems. Island Press, Washington, D.C., USA.

Davis, O. K., and W. D. Sellers. 1994. Orbital history and seasonality of regional precipitation. Human Ecology 22:97-113.

Day, R. H., and M. A. Pingle. 1991. Economizing economizing. Pages 509-522 in R. Frantz, H. Singh, and J. Gerber, editors. Behavioral decision-making: handbook of behavioral economics. JAI Press, Greenwich, Connecticut, USA.

de Groot, R.S. 1992. Functions of nature. WoltersNoordhoff, Amsterdam, The Netherlands.

Deutsch, L., S. Gräslund, C. Folke, M. Huitric, N. Kautsky, M. Troell, and L. Lebel. 2007. Feeding aquaculture growth through globalization; exploitation of marine ecosystems for fishmeal. Global Environmental Change 17:238-249.

Diamond, J. 2005. Collapse: how societies choose to fail or survive. Allen Lane, London, UK.

Dietz, T., E. Ostrom, and P. Stern. 2003. The struggle to govern the commons. Science 302:1907-1912.

Dornbusch, R., and S. Edwards. 1991. The macroeconomics of populism in Latin America. University of Chicago Press, Chicago, Illinois, USA.

Eddy, J. A. 1994. Solar history and human affairs. Human Ecology 22:23-35.

Ehrlich, P. R., and H. A. Mooney. 1983. Extinction, substitution and ecosystem services. BioScience 33:248-254.

Ekins, P., C. Folke, and R. Costanza. 1994. Trade, environment and development: the issues in perspective. Ecological Economics 9:1-12.

Elmqvist, T., C. Folke, M. Nyström, G. D. Peterson, J. Bengtsson, B. H. Walker, and J. Norberg. 2003. Response diversity and ecosystem resilience. Frontiers in Ecology and the Environment 1:488-494.

Farvar, M. T., and J. P. Milton, editors. 1972. Careless technology: ecology and international development. Natural History Press, Garden City, New York, USA.

Finlayson, A. C., and B. J. McCay. 1998. Crossing the threshold of ecosystem resilience: the commercial extinction of northern cod. Pages 
311-337 in F. Berkes and C. Folke, editors. Linking social and ecological systems: management practices and social mechanisms for building resilience. Cambridge University Press, Cambridge, UK.

Foley, J. A., R. DeFries, G. P. Asner, C. Barford, G. Bonan, S. R. Carpenter, F. S. Chapin, M. T. Coe, G. C. Daily, H. K. Gibbs, J. H. Helkowski, T. Holloway, E. A. Howard, C. J. Kucharik, C. Monfreda, J. A. Patz, I. C. Prentice, N. Ramankutty, and P. K. Snyder. 2005. Global consequences of land use. Science 309:570-574.

Folke, C. 1991. Socioeconomic dependence on the life-supporting environment. Pages 77-94 in C. Folke and T. Kåberger, editors. Linking the natural environment and the economy: essays from the EcoEco Group. Kluwer Academic Publishers, Dordrecht, The Netherlands.

Folke, C. 2006. Resilience: the emergence of a perspective for social-ecological systems analyses. Global Environmental Change 16:253-267.

Folke, C., F. Berkes, and J. Colding. 1998a. Ecological practices and social mechanisms for building resilience and sustainability. Pages 414-436 in F. Berkes, and C. Folke, editors. Linking social and ecological systems: management practices and social mechanisms for building resilience. Cambridge University Press, Cambridge, UK.

Folke, C., S. R. Carpenter, B. H. Walker, M. Scheffer, T. EImqvist, L. H. Gunderson, and C. S. Holling. 2004. Regime shifts, resilience and biodiversity in ecosystem management. Annual Review of Ecology, Evolution and Systematics 35:557-581.

Folke, C., T. Hahn, P. Olsson, and J. Norberg. 2005. Adaptive governance of social-ecological systems. Annual Review of Environment and Resources 30:441-473.

Folke, C., C. S. Holling, and C. Perrings. 1996. Biological diversity, ecosystems, and the human scale. Ecological Applications 6:1018-1024.

Folke, C, L. Pritchard, F. Berkes, J. Colding, and U. Svedin. 1998b. The problem of fit between ecosystems and institutions. IHDP Working Paper No. 2. International Human Dimensions Program on Global Environmental Change, Bonn, Germany. Available online at: http://www.ihdp.uni-bonn.de/html/ publications/workingpaper/wp02m.htm.

Foster, D. R. 1992. Land-use history (1730-1990) and vegetation dynamics in central New England, USA. Journal of Ecology 80:753-772.

Gadgil, M., and F. Berkes. 1991. Traditional resource management systems. Resource Management and Optimization 18:127-141.

Gadgil, M., F. Berkes, and C. Folke. 1993. Indigenous knowledge for biodiversity conservation. Ambio 22:151-156.

Gadgil, M., N. S. Hemam, and B. M. Reddy. 1998. People, refugia and resilience. Pages 30-47 in F. Berkes, and C. Folke, editors. Linking social and ecological systems: management practices and social mechanisms for building resilience. Cambridge University Press, Cambridge, UK.

Galaz, V., T. Hahn, P. Olsson, C. Folke, and U. Svedin. 2007. The problem of fit between ecosystems and governance systems: insights and emerging challenges. In O. Young, L. A. King, and $\mathrm{H}$. Schroeder, editors. The institutional dimensions of global environmental change: principal findings and future directions. MIT Press, Boston, Massachusetts, USA, in press.

Geoghegan, J., L. Pritchard, Y. OgnevaHimmelberger, R. R. Chowdhury, S. Sanderson, and B. L. Turner II. 1998. Socializing the pixel and pixelizing the social in land-use and land-cover changes. Pages 51-59 in D. Liverman, E. Moran, R. Rindfuss, and P. Stern, editors. People and pixels: linking remote sensing and social science. National Academy of Science Press, Washington, D.C., USA.

Goland, C. 1993. Field scattering as agricultural risk management: a case study from Cuyo-Cuyo, Department of Puno, Peru. Mountain Research and Development 13:317-338.

Gunderson, L. H., and C. S. Holling, editors. 2002. Panarchy: understanding transformations in human and natural systems. Island Press, Washington, D.C., USA.

Gunderson, L. H., C. S. Holling, and S. Light, editors. 1995. Barriers and bridges to the renewal 
of ecosystems and institutions. Columbia University Press, New York, New York, USA.

Gunderson, L. H., C. S. Holling, L. Pritchard, and G.D. Peterson. 1997. Resilience in ecosystems, institutions, and societies: propositions for a research agenda. Beijer Discussion Paper Series No. 95. Beijer International Institute of Ecological Economics, Stockholm, Sweden.

Hahn, F. 1987. Information, dynamics and equilibrium. Scottish Journal of Political Economy 34:321-324.

Hames, R. 1991. Wildlife conservation in tribal societies. Pages 172-199 in M. L. Oldfield, and J. B. Alcorn, editors. Biodiversity: culture, conservation, and ecodevelopment. Westview Press, Boulder, Colorado, USA.

Hanna, S. 1998. Managing for human and ecological context in the Maine soft shell clam fishery. Pages 190-211 in F. Berkes, and C. Folke, editors. Linking social and ecological systems: management practices and social mechanisms for building resilience. Cambridge University Press, Cambridge, UK.

Hanna, S., C. Folke, and K.-G. Mäler, editors. 1996. Rights to nature: ecological, economic, cultural, and political principles of institutions for the environment. Island Press, Washington, D.C., USA.

Heiner, R. A. 1983. The origin of predictable behavior. American Economic Review 73:560-595.

Holling, C. S. 1973. Resilience and stability of ecological systems. Annual Review of Ecology and Systematics 4:1-23.

Holling, C. S. 1986. The resilience of terrestrial ecosystems: local surprise and global change. Pages 292-317 in W. C. Clark and R. E. Munn, editors. Sustainable development of the Biosphere. Cambridge University Press, London, UK.

Holling, C. S. 1994. An ecologists view of the Malthusian conflict. Pages 79-103 in K. LindahlKiessling and H. Landberg, editors. Population, economic development, and the environment. Oxford University Press, Oxford, UK.

Holling, C. S., F. Berkes, and C. Folke. 1998. Science, sustainability, and resource management.
Pages 342-362 in F. Berkes, and C. Folke, editors. Linking social and ecological systems: management practices and social mechanisms for building resilience. Cambridge University Press, Cambridge, UK.

Holling, C. S., and S. Sanderson. 1996. Dynamics of (dis)harmony in ecological and social systems. Pages 57-85 in S. Hanna, C. Folke, and K.-G. Mäler, editors. Rights to nature: ecological, economic, cultural, and political principles of institutions for the environment. Island Press, Washington, D.C., USA.

Holling, C. S., D. W. Schindler, B. H. Walker, and J. Roughgarden. 1995. Biodiversity in the functioning of ecosystems: an ecological synthesis. Pages 44-83 in C. A. Perrings, K.-G. Mäler, C. Folke, C. S. Holling, and B.-O. Jansson, editors. Biodiversity loss: economic and ecological issues. Cambridge University Press, Cambridge, UK.

Houghton, J. T., L. G. Meira Filho, B. A. Callander, N. Harris, A. Kattenberg, and K. Maskell. 1996. Climate change 1995: the science of climate change. Cambridge University Press, Cambridge, UK.

Hughes, T. P. 1994. Catastrophe, phase shifts and large scale degradation of a Caribbean coral reef. Science 226: 1547-1549.

Huitric, M. 2005. Lobster and conch fisheries of Belize: a history of sequential exploitation. Ecology and Society 10(1): 21. [online] URL: http://www.e cologyandsociety.org/vol10/iss1/art21/.

Imperial, M. T. 2005. Using collaboration as a governance strategy: lessons from six watershed management programs. Administration \& Society 37:281-320.

Jackson, J. B. C., M. X. Kirb, W. H. Berher, K. A. Bjorndal, L. W. Botsford, B. J. Bourque, R. H. Bradbury, R. Cooke, J. Erlandsson, J. A. Estes, T. P. Hughes, S. Kidwell, C. B. Lange, H. S. Lenihan, J. M. Pandolfi, C. H. Peterson, R. S. Steneck, M. J. Tegner, and R. R. Warner. 2001. Historical overfishing and the recent collapse of coastal ecosystems. Science 293:629-638.

Jamieson, N. L., and G. W. Lovelace. 1985. Cultural values and human ecology: some initial considerations. Pages 27-54 in K. L. Hutterer, A. T. Rambo, and G. W. Lovelace, editors. Cultural 
values and human ecology in Southeast Asia. Center for South and Southeast Asian Studies, University of Michigan, Ann Arbor, Michigan, USA.

Jansson, A. M., M. Hammer, C. Folke, and R. Costanza, editors. 1994. Investing in natural capital: the ecological economics approach to sustainability. Island Press, Washington D.C., USA.

Jodha, N. S. 1995. Environmental crisis and unsustainability in Himalayas: lessons from the degradation process. Pages 183-206 in S. Hanna and M. Munasinghe, editors. Property rights in a social and ecological context: case studies and design applications. Beijer International Institute of Ecological Economics and the World Bank, Washington, D.C., USA.

Johannes, R. E. 1978. Traditional marine conservation methods in Oceania and their demise. Annual Review of Ecology and Systematics 9:349-364.

Johnson, A. W., and T. K. Earle. 1987. The evolution of human societies: from foraging group to agrarian state. Stanford University Press, Palo Alto, California, USA.

Kasperson, J. X., R. E. Kasperson, and B. L. Turner. 1996. Regions at risk: exploring environmental criticality. Environment 38:4-15, 26-29.

Kinzig, A. P., P. Ryan, M. Etienne, H. Allison, T. Elmqvist, and B. H. Walker. 2006. Resilience and regime shifts: assessing cascading effects. Ecology and Society 11(1): 20. [online] URL: http://www.ec ologyandsociety.org/vol11/iss1/art20/

Kinzig, A. P., D. Starrett, K. Arrow, B. Bolin, P. Dasgupta, P. R. Ehrlich, C. Folke, M. Hanemann , G. Heal, M. Hoel, A. - M. Jansson, B.- O. Jansson, N. Kautsky, S. A. Levin, J. Lubchenco, K.- G. Mäler, S. Pacala, S. Schneider, D. Siniscalco, and B. H. Walker. 2003. Coping with uncertainty: a call for a new science-policy forum. Ambio 32:330-335.

Knowlton, N. 1992. Thresholds and multiple atable states in coral reef community dynamics. American Zoologist 32:674-682.

Krugman, P. R. 1991. Geography and trade. MIT Press, Cambridge, Massachusetts, USA.
Kuhn, T. S. 1962. The structure of scientific revolutions. University of Chicago Press, Chicago, Illinois, USA.

Kuran, T. 1988. The tenacious past: theories of personal and collective conservatism. Journal of Economic Behavior and Organization 10:143-171.

Lambin, E. F., H. J. Geist, and E. Lepers. 2003. Dynamics of land-use and land-cover change in tropical regions. Annual Review of Environment and Resources 28:205-241.

Lee, K. N. 1993. Greed, scale mismatch, and learning. Ecological Applications 3:560-564.

Levin, S. A. 1992. The problem of pattern and scale in ecology. Ecology 73:1943-1967.

Levin, S. A. 1997. Biodiversity: nterfacing populations and ecosystems. Pages 277-288 in T. Abe, S. A. Levin, and M. Higashi, editors. Biodiversity: an ecological perspective. SpringerVerlag, New York, New York, USA.

Levin, S. A. 1999. Fragile dominion: complexity and the commons. Perseus Books, Reading, Massachusetts, USA.

Levin, S. A., S. Barrett, W. Baumol, C. Bliss, B. Bolin, N. Chichinsky, P. Dasgupta, P. Ehrlich, C. Folke, I. M. Gren, C. S. Holling, A. M. Jansson, B.-O. Jansson, K.-G. Mäler, and C. Perrings. 1998. Resilience in natural and socioeconomic systems. Environment and Development Economics 3: $222-235$.

Light, S. S. 1983. Anatomy of surprise. Dissertation. University of Michigan, Ann Arbor, Michigan, USA.

Liljenstrom, H. and U. Svedin, editors. 2005. Micro, meso, macro: addressing complex systems couplings. World Scientific, London, UK.

Lindblom, C. F. 1990. Inquiry and change: the troubled attempt to understand and shape society. Yale University Press, New Haven, Connecticut, USA.

Ludwig, D., B. H. Walker, and C. S. Holling. 1997. Sustainability, stability and resilience. Conservation Ecology 1(1): 7. [online] URL: http://www.consecol. org/vol1/iss1/art7. 
Ludwig, D., R. Hilborn, and C. Walters. 1993. Uncertainty, resource exploitation and conservation: lessons from history. Science 260: 17, 36.

Mather, A. S., C. L. Needle, and J. Fairbairn. 1998. The human drivers of global land cover change: the case of forests. Hydrological Processes 12:1983-1994.

McCloskey, D. N. 1991. The prudent peasant: new findings on open fields. Journal of Economic History 51:343-355.

McDonnell, M. J. and S. T. A. Pickett, editors. 1993. Humans as components of ecosystems: the ecology of subtle human effects and populated areas. Springer-Verlag, New York, New York, USA.

McKean, M. A. 1996. Common-property regimes as a solution to problems of scale and linkage. Pages 223-243 in S. Hanna, C. Folke, and K.-G. Mäler, editors. Rights to nature: ecological, economic, cultural, and political principles of institutions for the environment. Island Press, Washington, D.C., USA.

McMichael, A. J., A. Haines, R. Slooff, and S. Kovats. 1996. Climate change and human health. WHO, Geneva, Switzerland.

Mitsch, W. J., and S. E. Jörgensen. 1989. Ecological engineering: an introduction to ecotechnology. Wiley, New York, New York, USA.

Naiman, R. J. 1992. Watershed management: balancing sustainability and environmental change. Springer-Verlag, New York, New York, USA.

Netting, R. 1993. Smallholders, householders: farm families and the ecology of intensive, sustainable agriculture. Stanford University Press, Stanford, California, USA.

Niamir-Fuller, M. 1998. The resilience of pastoral herding in Sahelian Africa. Pages 250-284 in F. Berkes and C. Folke, editors. Linking social and ecological systems: management practices and social mechanisms for building resilience. Cambridge University Press, Cambridge, UK.

Norberg, J. and G. S. Cumming, editors. 2007.
Complexity theory for a sustainable future. Columbia University Press, New York, New York, USA.

North, D. C. 1990. Institutions, institutional change and economic performance. Cambridge University Press, Cambridge, UK.

North, D. C. 1993. What do we mean by rationality? Public Choice 77:159-162.

Odum, E. P. 1989. Ecology and our endangered life-support systems. Sinauer Associates, Sunderland, Massachussets, USA.

Odum, H. T. 1971. Environment, power, and society. Wiley-Interscience, New York, New York, USA.

Olsson, P., C. Folke, and F. Berkes. 2004a. Adaptive co-management for building socialecological resilience. Environmental Management 34:75-90.

Olsson, P., T. Hahn, and C. Folke. 2004b. Socialecological transformation for ecosystem management: the development of adaptive co-management of a wetland landscape in southern Sweden. Ecology and Society 9(4): 2. [online] URL: http://www.ecol ogyandsociety.org/vol9/iss4/art2.

O’Neill, R. V., D. L. DeAngelis, J. B. Wade, and T. F. H. Allen. 1986. A hierarchial concept of ecosystems. Princeton University Press, Princteon, New Jersey, USA.

Ostrom, E. 1990. Governing the commons: the evolution of institutions for collective actions. Cambridge University Press, Cambridge, UK.

Ostrom, E., T. Dietz, N. Dolsak, P. Stern, S. Stonich, and E. U. Weber, editors. 2002. The drama of the commons. National Academy Press, Washington, D.C., USA.

Pahl-Wostl, C., and M. Hare. 2004. Processes of social learning in integrated resources management. Journal of Community and Applied Social Psychology 14:193-206.

Peluso, N. L. 1992. Rich forests, poor people: resource control and resistance in Java. University of California Press, Berkeley, California, USA. 
Peterson, G. D., C. R. Allen, and C. S. Holling. 1998. Ecological resilience, biodiversity, and scale. Ecosystems 1:6-18.

Philander, G. 1989. El Niño and La Niña. Scientific American 77:451-459.

Pinkerton, E. 1998. Integrated management of a temperate montane forest ecosystem through wholistic forestry: a British Columbia example. Pages 363-389 in F. Berkes, and C. Folke, editors. Linking social and ecological systems: management practices and social mechanisms for building resilience. Cambridge University Press, Cambridge, UK.

Redford, K. H. 1990. The ecologically noble savage. Cultural Survival Quarterly 15:46-48.

Redman, C. L. 1999. Human impact on ancient environments. University of Arizona Press, Tucson, Arizona, USA.

Regier, H. A., and G. L. Baskerville. 1986. Sustainable redevelopment of regional ecosystems degraded by exploitive development. Pages 75-101 in W. C. Clark and R. E. Munn, editors. Sustainable development of the Biosphere. Cambridge University Press, Cambridge, UK.

Reid, W. V., F. Berkes, T. Wilbanks, and D. Capistrano, editors. 2006. Bridging scales and knowledge systems: linking global science and local knowledge in assessments. Island Press, Washington D.C., USA

Ruddle, K., E. Hviding, and R. E. Johannes. 1992. Marine resources management in the context of customary marine tenure. Marine Resource Economics 7:249-273.

Sanderson, S. E., and L. Pritchard. 1998a. The external drivers of deforestation and regrowth. Workshop Report: IGBP/IHDP Land Use and Cover Change Project Focus 1 Workshop held in Marathon, Florida, February 20-23, 1997.

Sanderson, S. E., and L. Pritchard. 1998b. The social meaning of secondary growth. Workshop Report: IGBP/IHDP Land Use and Cover Change Project Focus 1 Workshop held in Gainesville, Florida, September 19-22, 1997.

Scheffer, M., S. R. Carpenter, J. Foley, C. Folke, and B. H. Walker. 2001. Catastrophic shifts in ecosystems. Nature 413:591-696.

Scheffer, M., S. H. Hosper, M.-L. Meyjer, B. Moss, and E. Jeppsen. 1993. Alternative equilibria in shallow lakes. Trends in Ecology and Evolution 8:275-279

Schumpeter, J.A. 1950. Capitalism, socialism and democracy. Harper and Row, New York, New York, USA.

Schwartz, G. M., and J. J. Nichols, editors. 2006. After collapse: the regeneration of complex societies. The University of Arizona Press, Tucson, Arizona, USA.

Shipton, P. 1988. The Kenyan land tenure reform; misunderstanding in the public creation of private property. Pages 91-135 in R. E. Downs and S. P. Reyna, editors. Land and society in contemporary Africa. University Press of New England, Hanover, New Hampshire, USA.

Skole, D. L., and C. Tucker. 1993. Tropical deforestation and habitat fragmentation in the Amazon: satellite data from 1978 to 1988 . Science 260:1905-1910.

Sousa, W.P. 1984. The role of disturbance in natural communities. Annual Review of Ecology and Systematics 15:353-391.

Steffen, W., A. Sanderson, J. Jäger, P. D. Tyson, B. Moore III, P. A. Matson, K. Richardson, F. Oldfield, H.-J. Schellnhuber, B. L. Turner, and R. J. Wasson. 2004. Global change and the Earth system: a planet under pressure. Springer Verlag, Heidelberg, Germany.

Sutton, J. D., and A. J. Webb. 1988. Trade policies and the use and value of natural resources. Pages 157-186 in J. D. Sutton, editor. Agricultural trade and natural resources. Lynne Riener, London, UK.

Taussig, M. 1987. Shamanism, colonialism, and the wild man: a study in terror and healing. University of Chicago Press, Chicago, Illinois, USA.

Tsing, A. L. 1993. In the realm of the diamond queen: marginality in an out-of-the-way place. Princeton University Press, Princeton, New Jersey, USA.

Turner, B. L., R. E. Kasperson, W. B. Meyer, K. M. Dow, D. Golding, J. X. Kasperson, R. C. 
Mitchell, and S. J. Ratick. 1990. Two types of global environmental change: definitional and spatial-scale issues in their human dimensions. Global Environmental Change 1:14-22.

Turner, B. L., W. C. Clark, and W. C. Kates, editors. 1990. The Earth as transformed by human action: global and regional changes in the biosphere over the past 300 years. Cambridge University Press, Cambridge, UK.

Turner, B. L., R. H. Moss, and D. L. Skole, editors. 1993. Relating land use and global landcover change: a proposal for an IGBP-HDP Core Project. International Geosphere-Biosphere Programme, Stockholm, Sweden.

Turner, M. G. 1989. Landscape ecology: the effect of pattern on process. Annual Review of Ecology and Systematics 20:171-197.

van der Leeuw, S. E. 2000. Land degradation as a socionatural process. Pages 190-210 in R .J. McIntosh, J. A. Tainter, and S. K. McIntosh, editors. The way the wind blows: climate, history and human action. Columbia University Press, New York, New York, USA.

Vitousek, P. M. 1994. Beyond global warming: ecology and global change. Ecology 75:1861-1876.

Walker, B. H. 1992. Biodiversity and ecological redundancy. Conservation Biology 6:18-23.

Walters, C. J. 1986. Adaptive management of renewable resources. McGraw-Hill, New York, New York, USA.

Warren, D. M., and J. Pinkston. 1998. Indigenous African resource management of a tropical rain forest ecosystem: a case study of the Yoruba of Ara, Nigeria. Pages 158-189 in F. Berkes, and C. Folke, editors. Linking social and ecological systems: management practices and social mechanisms for building resilience. Cambridge University Press, Cambridge, UK.

Westoby, M., B. H. Walker, and I. Noy-Meir. 1989. Opportunistic management for rangelands not at equilibrium. Journal of Rangeland Management 42:266-274.

White, L., Jr. 1967. The historical roots of our ecological crisis. Science 155:1203-1207.
Wilson, J. A. 2006. Matching social and ecological systems in complex ocean fisheries. Ecology and Society 11(1): 9. [online] URL: http://www.ecology andsociety.org/vol11/iss 1/art9/.

Wilson, J.A., R. Townsend, P. Kelban, S. McKay, and J. French. 1990. Managing unpredictable resources: traditional policies applied to chaotic populations. Ocean and Shoreline Management 13:179-197.

Young, O. R. 2002. The institutional dimensions of environmental change: fit, interplay and scale. Cambridge University Press, Cambridge, UK.

Young, O. R., F. Berkhout, G. C. Gallopin, M. A. Janssen, E. Ostrom, and S. van der Leeuw. 2006. The globalization of socio-ecological systems: an agenda for scientific research. Global Environmental Change 16:304-316.

Young, O. R., L. A. King, and H. Schroeder, editors. 2007. The institutional dimensions of global environmental change: principal findings and future directions. MIT Press, Boston, Massachusetts, USA .

Young, O., and A. Underdal. 1997. Institutional dimensions of global change. IHDP Scoping Report. International Human Dimensions Programme on Global Environmental Change, Bonn, Germany. 